https://doi.org/10.15407/ufm.19.03.309

PACS numbers: 61.66.Dk, 61.72.Ff, 61.72. Hh, 62.20.M-, 68.37.Hk, 68.55.jd, 81.05.Bx, 81.10.Fq,

81.20. Hy, 81.40.Ef, 81.40.Jj, 81.40.Np, 81.70.Bt, 83.50.Uv, 83.60.Pq

O.M. IVASISHIN ' ${ }^{\text {, S.V. AKHONIN }}{ }^{2}$, D.G. SAVVAKIN ${ }^{\text {', V.A. BEREZOS }}{ }^{2}$, V.I. BONDARCHUK' ${ }^{\prime}$, O.O. STASYUK' ${ }^{\prime}$, and P.E. MARKOVSKY ${ }^{1}$

' G.V. Kurdyumov Institute for Metal Physics, NAS of Ukraine,

36 Academician Vernadsky Blvd, UA-03 142 Kyiv, Ukraine

${ }^{2}$ Ye.O. Paton Electric Welding Institute, NAS of Ukraine,

11 Kazimir Malevich Str., UA-03150 Kyiv, Ukraine

\title{
EFFECT OF MICROSTRUCTURE, DEFORMATION MODE AND RATE ON MECHANICAL BEHAVIOUR OF ELECTRON-BEAM MELTED Ti-6AI-4V AND Ti-1.5Al-6.8Mo-4.5Fe ALLOYS
}

Two commercial cost-efficient titanium alloys-a low-alloyed $\alpha+\beta-\mathrm{Ti}-6 \mathrm{Al}-4 \mathrm{~V}$ (mas. $\%$ ) and a metastable $\beta$-alloy $\mathrm{Ti}-1.5 \mathrm{Al}-6.8 \mathrm{Mo}-4.5 \mathrm{Fe}$ melted with a single electron-beam cold hearth melting approach-are employed in a present study as program materials. The influence of microstructure formed by means of the subsequent thermomechanical and heat treatments on both the mechanical behaviour (evaluated by the deformation energy, $U_{\mathrm{D}}$ ) when tested using standard methods with different deformation rates and the ballistic resistance of plate materials is investigated. As revealed, the weakest dependence of $U_{\mathrm{D}}$ on the strain rate corresponds to Ti-6 $\mathrm{Al}-4 \mathrm{~V}$ alloy with microstructure morphology close to globular one, whereas in the same alloy with a lamellar microstructure (annealed in a single-phase $\beta$-field) as well as in $\mathrm{Ti}-1.5 \mathrm{Al}-6.8 \mathrm{Mo}-4.5 \mathrm{Fe}$ alloy with various microstructures, $U_{\mathrm{D}}$ values significantly depend on the rate of deformation. Moreover, only after annealing at a temperature of the two-phase $\alpha+\beta$ field, the $U_{\mathrm{D}}$ value for $\mathrm{Ti}-6 \mathrm{Al}-4 \mathrm{~V}$ upon three-point flexure at varying deformation rate is equal to the sum of the corresponding values obtained under tension and compression. During subsequent ballistic tests of plates of different thicknesses, it is established that the best ballistic impact resistance corresponds to the materials with higher $U_{\mathrm{D}}$ values and lower strain-rate sensitivity. The damage of alloys during all types of testing is discussed in detail in terms of possible mechanisms of deformation and fracture.

Keywords: titanium alloys, microstructure, mechanical properties, mechanical behaviour, deformation rates, deformation energy, ballistic tests. 


\section{Introduction}

The titanium-based alloys and coatings are a unique class of structural materials for many applications, and first of all aerospace and military, due to their high specific strength, fatigue endurance, resistances to crack growth and corrosion [1-6]. In some cases, these materials are employed in parts working at high stresses and tough operating conditions, particularly, in parts subjected to high-rate deformations and high strengths. For instance, similar service conditions will take place in the new generation of civil supersonic aircraft $[7,8]$ as well as in a wide range of products for military use $[9,10]$. Application of titanium alloys as armour material is an extreme case of their use from the viewpoint of mechanical properties. There is a large number of published up to now works on the ballistic impact behaviour of different titanium alloys tested with different types of projectiles [9-19], but only few of them paid some attention to different types of microstructure, and no unambiguous relationships between microstructure and ballistic properties have been revealed $[15,18]$. At the same time, in some previous works, we showed the determining role of phase composition and microstructure in the mechanical behaviour of various titanium alloys tested with different deformation rates (quasi-static range) on tension, compression and three-point bending [20-22]. Earlier [23, 24], Ti-6Al-4V (wt.\%) alloy produced via single-melt electron-beam with cold hearth melting (EBCH) and then milled to assigned thickness without any final annealing was recognized as the most appropriate titanium armour material from the viewpoint of price/properties (or reliability) ratio.

The goal of this work was to evaluate real possibility to improve mechanical behaviour under deformation with different rates, and, finally, to enhance ballistic properties of two titanium cost-efficient alloys $\mathrm{Ti}-6 \mathrm{Al}-4 \mathrm{~V}$ and $\mathrm{Ti}-1.5 \mathrm{Al}-6.8 \mathrm{Mo}-4.5 \mathrm{Fe}$ (wt.\%) (so-called 'low cost beta') produced with above-mentioned melting technique. To achieve this goal, we used various types of subsequent heat treatment, which allowed varying the structural and phase state of the alloys. With the aim to evaluate possibility to obtain the best ballistic impact protection properties, a special surface rapid heat treatment (SRHT) was employed for the both alloys that allowed forming gradient microstructure with strengthened surface layer combined with a ductile core [25-27].

\section{Materials and Experimental Procedure}

Two above mentioned alloys were melted with EBCH melting approach in the form of $100 \mathrm{~mm}$ diameter and about $200 \mathrm{~mm}$ long ingots, using titanium sponge and $\mathrm{Al}-\mathrm{V}$ master alloy (for $\mathrm{Ti}-6 \mathrm{Al}-4 \mathrm{~V}$ ) or pure $\mathrm{Al}, \mathrm{Fe}$ and $\mathrm{Mo}$ (for $\mathrm{Ti}-1.5 \mathrm{Al}-6.8 \mathrm{Mo}-4.5 \mathrm{Fe}$ ). The ingots were melted at laboratory electronic beam unit UE-208 [28] by single melting. Real chemical 
compositions of melted ingots (averaged for three different locations of ingots) were as follow: (i) $\mathrm{Ti}-5.8 \mathrm{Al}-3.86 \mathrm{~V}$ and (ii) $\mathrm{Ti}-1.6 \mathrm{Al}-6.3 \mathrm{Mo}-$ $4.36 \mathrm{Fe}$ (wt.\%). The ingots were subjected to superficial turning and subsequent $3 D$ pressing with total reduction of about $60 \%$ at singlephase $\beta$-temperatures: starting temperature was $1100^{\circ} \mathrm{C}$ and $900^{\circ} \mathrm{C}$ for the $\mathrm{Ti}-6 \mathrm{Al}-4 \mathrm{~V}$ and $\mathrm{Ti}-1.5 \mathrm{Al}-6.8 \mathrm{Mo}-4.5 \mathrm{Fe}$, respectively. In more detail, the melting and thermomechanical processing of $\mathrm{Ti}-6 \mathrm{Al}-4 \mathrm{~V}$ and $\mathrm{Ti}-1.5 \mathrm{Al}-6.8 \mathrm{Mo}-4.5 \mathrm{Fe}$ alloys were described in [29] and [30], respectively. After hot pressing, both alloys were rolled in standard mills at temperatures of two-phase $\alpha+\beta$ field: $\mathrm{Ti}-6 \mathrm{Al}-4 \mathrm{~V}$ at $880{ }^{\circ} \mathrm{C}$ to the final thicknesses of $23 \mathrm{~mm}$ and $11 \mathrm{~mm}$, and $\mathrm{Ti}-1.5 \mathrm{Al}-6.8 \mathrm{Mo}-4.5 \mathrm{Fe}$ at $750{ }^{\circ} \mathrm{C}$ to the thickness of $11 \mathrm{~mm}$. Some rolled plates were annealed at different temperatures of two-phase $\alpha+\beta$ and single- $\beta$-phase fields with aim to obtain different types of microstructure. The SRHT was performed at special induction heating device developed at the G.V. Kurdyumov Institute for Metal Physics of the National Academy of Sciences of Ukraine [31]. All types and regimes of treatments employed in the present study are listed in Table 1. Their application allowed us to obtain a wide range of structural conditions, which varied in phase composition, type and fineness of microstructure, and to form gradient states with hardened surfaces combined with a ductile core.

Table 1. Treatments and microstructural states

\begin{tabular}{|c|c|c|c|}
\hline \#\# & Type of treatment & Regime of treatment & Microstructure \\
\hline \multicolumn{4}{|c|}{$\mathrm{Ti}-6 \mathrm{Al}-4 \mathrm{~V}$} \\
\hline 1 & Hot deformation & $\begin{array}{l}\text { 3D hot pressing }+ \text { rolling } \\
\text { at } 880^{\circ} \mathrm{C}\end{array}$ & $\begin{array}{l}\text { Laminated, not recrystal- } \\
\text { lized, unstable }\end{array}$ \\
\hline 2 & $\begin{array}{l}\text { Annealing } \\
\text { in the } \alpha+\beta \text {-field }\end{array}$ & $\begin{array}{l}880^{\circ} \mathrm{C}, 1 \mathrm{~h}, \\
\text { furnace cooling }\end{array}$ & $\begin{array}{l}\text { Laminated, not recrystal- } \\
\text { lized, stabilized }\end{array}$ \\
\hline 3 & $\begin{array}{l}\text { Annealing } \\
\text { in the } \beta \text {-field }\end{array}$ & $\begin{array}{l}1100^{\circ} \mathrm{C}, 1 \mathrm{~h}, \\
\text { furnace cooling }\end{array}$ & Coarse-grained lamellar \\
\hline 4 & $\begin{array}{l}\text { Surface rapid } \\
\text { heat treatment }\end{array}$ & $\begin{array}{l}80 \mathrm{kWt}, 66 \mathrm{kHz}, 1000 \mathrm{~A}, \\
3 \mathrm{~mm} / \mathrm{s}+\text { aging } 550^{\circ} \mathrm{C}, 6 \mathrm{~h}\end{array}$ & $\begin{array}{l}\text { Gradient: hardened sur- } \\
\text { face (UTS } \geq 1300 \mathrm{MPa} \\
\text { [29]), laminated core }\end{array}$ \\
\hline \multicolumn{4}{|c|}{$\mathrm{Ti}-1.5 \mathrm{Al}-6.8 \mathrm{Mo}-4.5 \mathrm{Fe}$} \\
\hline 5 & Hot deformation & $\begin{array}{l}3 \mathrm{D} \text { hot pressing }+ \text { rolling at } \\
750^{\circ} \mathrm{C}\end{array}$ & $\begin{array}{l}\text { Laminated, not recrystal- } \\
\text { lized, unstable }\end{array}$ \\
\hline 6 & $\begin{array}{l}\text { Annealing } \\
\text { in the } \alpha+\beta \text {-field }\end{array}$ & $\begin{array}{l}750^{\circ} \mathrm{C}, 1 \mathrm{~h}, \\
\text { furnace cooling }\end{array}$ & $\begin{array}{l}\text { Elongated } \beta \text {-grains, globu- } \\
\operatorname{lar} \alpha \text {, stabilized }\end{array}$ \\
\hline 7 & $\begin{array}{l}\text { Quenching } \\
\text { from } \beta \text {-field }\end{array}$ & $\begin{array}{l}900^{\circ} \mathrm{C}, 0.5 \mathrm{~h}, \\
\text { water quenching }\end{array}$ & Single-phase metastable $\beta$ \\
\hline 8 & $\begin{array}{l}\text { Surface rapid } \\
\text { heat treatment }\end{array}$ & $\begin{array}{l}80 \mathrm{kWt}, 66 \mathrm{kHz}, 1000 \mathrm{~A}, \\
2.5 \mathrm{~mm} / \mathrm{s}+\operatorname{aging} 538^{\circ} \mathrm{C}, \\
6 \mathrm{~h}\end{array}$ & $\begin{array}{l}\text { Gradient: hardened sur- } \\
\text { face (UTS } \geq 1550 \mathrm{MPa} \\
\text { [30]), laminated } \alpha \text { core }\end{array}$ \\
\hline
\end{tabular}


Table 2. Characteristics of projectiles used in ballistic tests

\begin{tabular}{|c|c|c|c|c|c|c|}
\hline \#\# & Designation & $\begin{array}{c}\text { Bullet } \\
\text { Caliber, mm }\end{array}$ & $\begin{array}{c}\text { Bullet } \\
\text { Mass, g }\end{array}$ & Type of core & $\begin{array}{c}\text { Average } \\
\text { speed, m/sec }\end{array}$ & $\begin{array}{c}\text { Specific kinetic } \\
\text { energy, J/mm }\end{array}$ \\
\hline 1 & PP & 5.45 & 3.61 & $\begin{array}{l}\text { Hardened steel, } \\
\text { ogival shape } \\
\text { Soft steel, }\end{array}$ & $915 \pm 18$ & $65 \pm 4$ \\
3 & LPS & 7.62 & 9.62 & $\begin{array}{l}\text { Soft } \\
\text { ogival shape } \\
\text { Hardened steel, } \\
\text { ogival shape }\end{array}$ & $845 \pm 20$ & $78 \pm 5$ \\
\hline
\end{tabular}

Microstructure of alloys after different treatments was examined with light microscopy (LM) and scanning electron microscopy (SEM). The SEM was also employed for investigation of fracture surfaces of specimens after mechanical and ballistic tests. Tensile properties were studied in accordance with the ASTM E8M standard on specimens with gage length of $25 \mathrm{~mm}$ and gage diameter of $4 \mathrm{~mm}$ at INSTRON-3376 unit at different strain rates (quasi-static regimes). Three-point flexure tests were done on bar samples with dimensions of $60 \times 8 \times 8 \mathrm{~mm}$ at INSTRON 8802 unit. All specimens for mechanical tests were cut in rolling direction, and, at least, three specimens were tested for each microstructural state and deformation rate. Ballistic tests were performed in the certificated Laboratory at the Ivan Chernyakhovsky National University of Defence of Ukraine using ballistic barrels and projectiles listed in Table 2. The bullets had different calibres (diameters) and steel cores (non-hardened soft (LPS) with hardness comparable to the hardness of tested titanium alloys, i.e. about 300-350 HV, or thermally hardened (PP and B-32) with hardness above $750 \mathrm{HV}$ ). Different bullet masses and speeds allowed varying specific kinetic energy during tests. Ballistic tests were performed in accordance with Ukrainian Standards B4103-2002 and 3975-2000.

\section{Results}

\section{Microstructure}

Typical microstructures of the alloys after different processing routes are presented in Figs. 1 and 2. As seen from Fig. 1, hot deformation of cast $\mathrm{Ti}-6 \mathrm{Al}-4 \mathrm{~V}$ alloy did not lead to recrystallization, and microstructure was characterized by primary $\beta$-grains elongated in rolling direction with fine $\alpha$-lamellas grown inside from grain boundaries (Fig. 1, $a$ ). The thickness of these 'flattened' grains varied within the range of 20-100 $\mu \mathrm{m}$ due to intense and deep plastic deformation of initial cast structure, in which the $\beta$-grain size reached several tens (or even hundreds) of millimetres [29]. Further annealing at $880^{\circ} \mathrm{C}$ (this tempera- 

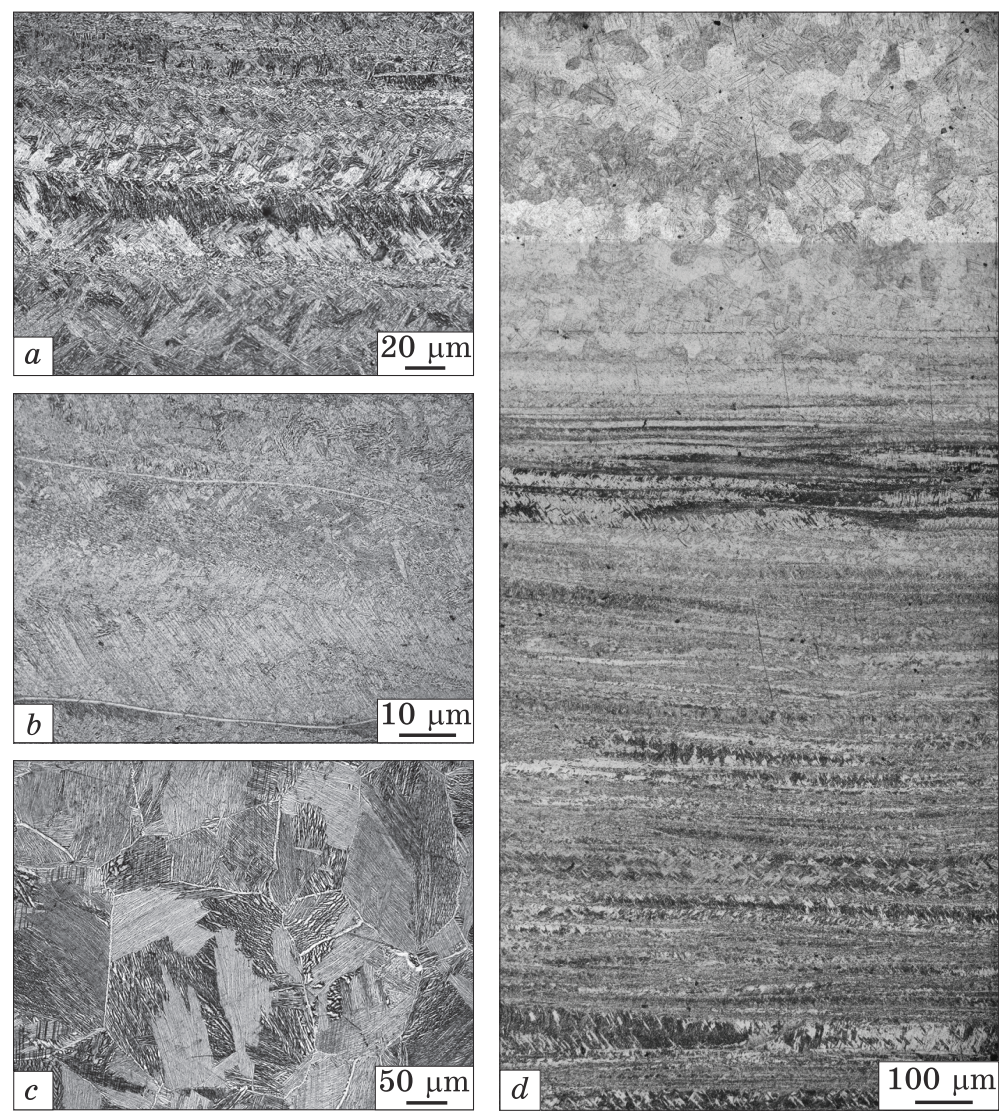

Fig. 1. Microstructure of $\mathrm{Ti}-6 \mathrm{Al}-4 \mathrm{~V}$ alloy in different states: $a-$ as-rolled, $b$ - after annealing at $880^{\circ} \mathrm{C}$ for $2 \mathrm{~h}, c$ - after annealing at $1100{ }^{\circ} \mathrm{C}$ for $1 \mathrm{~h}$, and $d-$ after SRHT with LM

ture corresponds to the $\alpha+\beta$ field) did not changed both grain and intragrain microstructure in as-rolled material (compare (Fig. 1, $a$ and $b$ ), but some $\beta$-grain boundaries (obviously, those with specific crystallographic orientation) were decorated by lamellar (or plate-like) $\alpha$-phase. This allows concluding that the density of defects introduced by rolling was not enough to initiate recrystallization even on subsequent annealing at temperatures of $\alpha+\beta$ field. The increase in annealing temperature up to $1100{ }^{\circ} \mathrm{C}$ (single-phase $\beta$-field for this alloy) naturally caused intense $\beta$-grain growth, and relatively coarse and inhomogeneous $\beta$-grain microstructure was formed with grain size varying from 50 to $500 \mu \mathrm{m}$ due to inheritance of non-uniformity of initial microstructure after annealing (Fig. 1, c).

After SRHT, the alloy had layered structure (Fig. 1, $d$ ), in which near-surface upper layers had thickness of about $4 \mathrm{~mm}$ and consisted of 

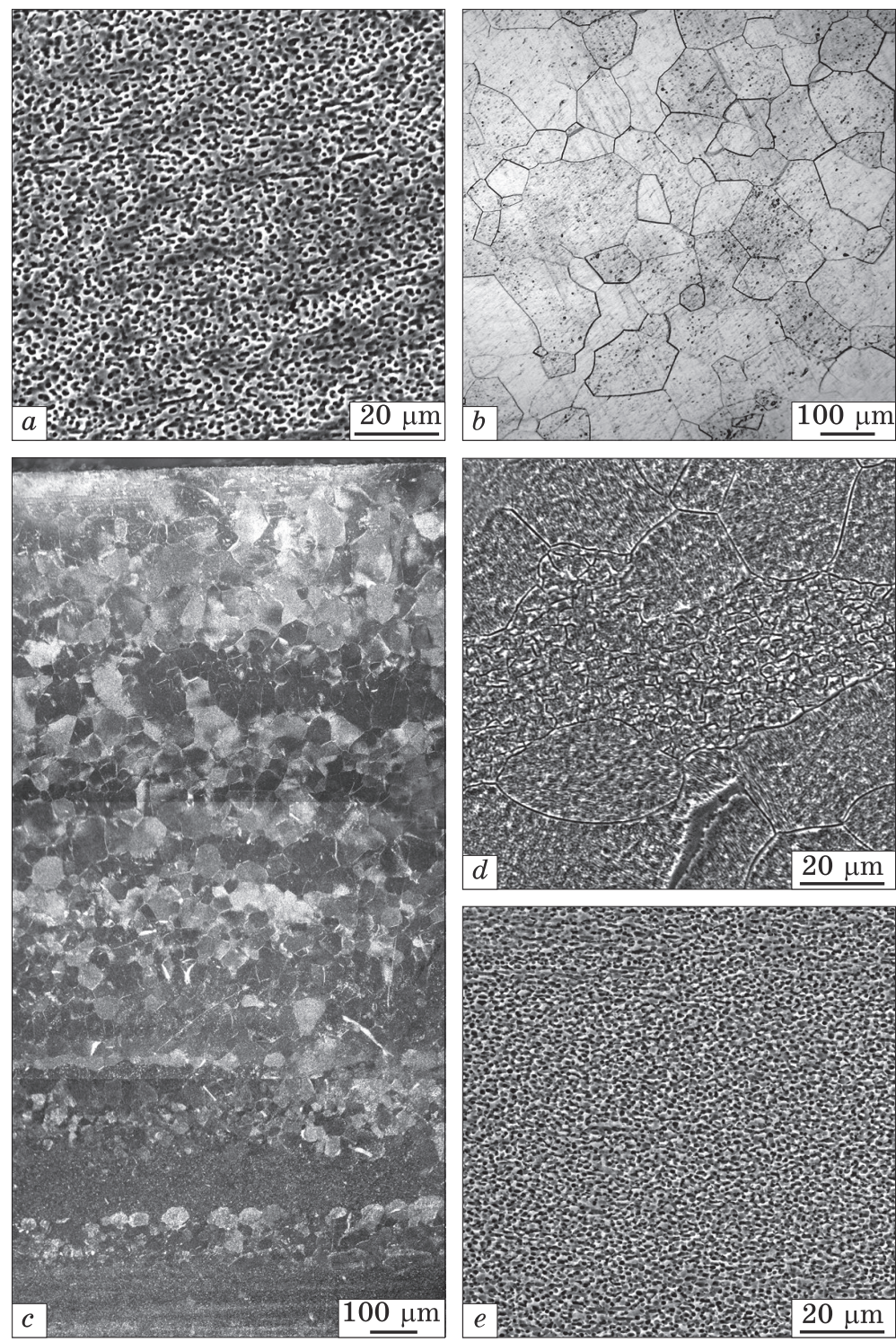

Fig. 2. Microstructure of $\mathrm{Ti}-1.5 \mathrm{Al}-6.8 \mathrm{Mo}-4.5 \mathrm{Fe}$ alloy in different states: $a-$ after rolling and annealing at $750{ }^{\circ} \mathrm{C}$ for $2 \mathrm{~h} ; b$ - after quenching from $900{ }^{\circ} \mathrm{C}$ into water (metastable $\beta$-state); $(c-e)$ - after SRHT, where $c$ - overall view, $d-$ surface layer, $e-$ core. Here, $a, d, e-\mathrm{SEM} ; b, c-\mathrm{LM}$

$\beta$-transformed microstructure formed as a result of $\alpha+\beta \rightarrow \beta$ transformation during rapid heating and subsequent $\beta \rightarrow \alpha\left(\alpha^{\prime}\right)+\beta$ decomposition upon cooling [32].

$\mathrm{Ti}-1.5 \mathrm{Al}-6.8 \mathrm{Mo}-4.5 \mathrm{Fe}$ alloy after hot deformation had laminated microstructure without elongated $\beta$-grains (Fig. 2, $a$; initial cast micro- 
structure of this alloy was discussed in detail earlier [30]). Subsequent annealing at $750{ }^{\circ} \mathrm{C}, 2 \mathrm{~h}$ (two-phase $\alpha+\beta$ field for this alloy) caused partial transformation of intragrain $\alpha$-phase from lamellar to globular one (Fig. 2, b). It is important to underline that, in both cases, $\beta$-grain boundaries were decorated by lamellar $\alpha$-phase, which is generally considered as a structural element that embrittles titanium alloys [2]. The application of SRHT to this alloy, like in above mentioned case, also led to formation of gradient microstructure (Fig. 2, c): the top layer (about $40 \mathrm{~mm}$ ) undergone $\alpha+\beta \rightarrow \beta$ transformation and consisted of $\beta$-transformed grains with diameter of 20-40 $\mu \mathrm{m}$ (Fig. 2, $d$ ), whereas deeper layers had initial fine globular-like microstructure (Fig. 2,e).

\section{Standard Mechanical Tests}

In present work, we did tensile and three-point flexure tests, while for the discussion and evaluation of the influence of deformation mode and rate on the mechanical behaviour of studied alloys we also used earlier results of compression tests [22].

\section{Tensile Tests}

The mechanical behaviour of both alloys under tension in dependence on their microstructure and tension rate was studied and discussed in detail in the previous work [21], including $\mathrm{Ti}-6 \mathrm{Al}-4 \mathrm{~V}$ and $\mathrm{Ti}-1.5 \mathrm{Al}-$ $6.8 \mathrm{Mo}-4.5 \mathrm{Fe}$ alloys produced by standard vacuum arc (VAR) melting and multistep deformation routes. It is necessary to underline once again that, in the present study, we employed single-melt EBCH alloy as starting material and subjected it to thermomechanical treatments described in the second section ('Materials and Experimental Procedure').

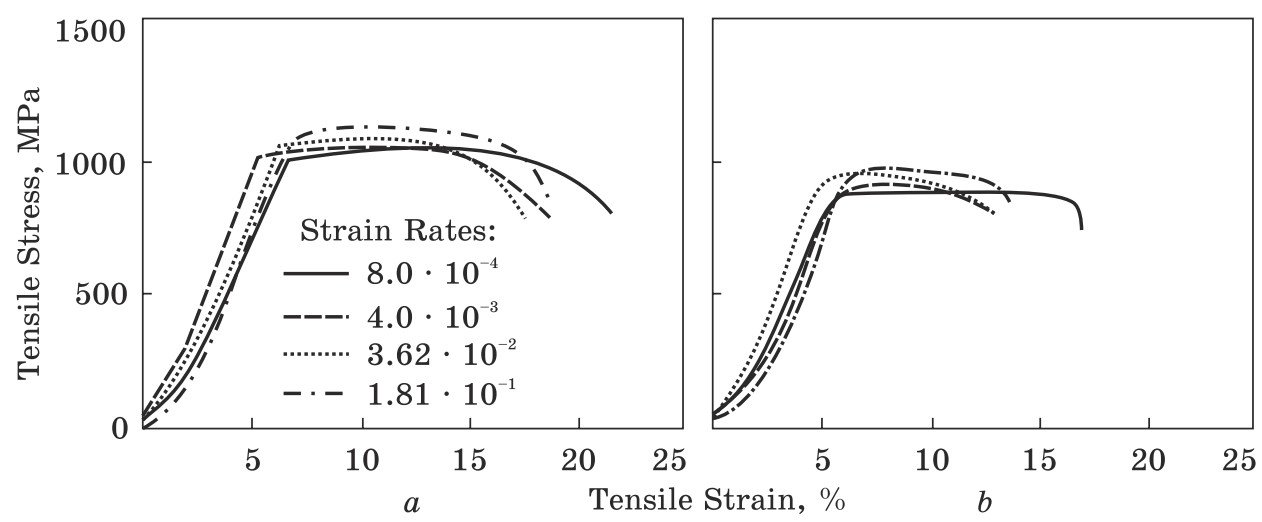

Fig. 3. Typical engineering stress-strain curves of $\mathrm{Ti}-6 \mathrm{Al}-4 \mathrm{~V}$ alloy tested at different strain rates after $1 \mathrm{~h}$ annealing at $880^{\circ} \mathrm{C}(a)$ and $1100{ }^{\circ} \mathrm{C}(b)$ 


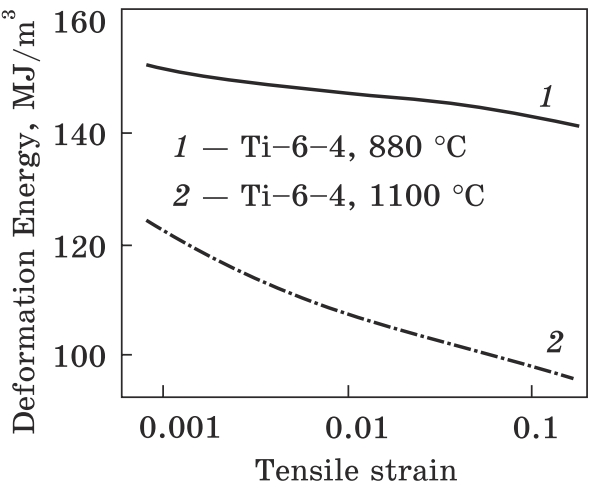

Fig. 4. Dependences of deformation energy on tension rate for $\mathrm{Ti}-6 \mathrm{Al}-4 \mathrm{~V}$ alloy in different structural conditions: annealing at $880^{\circ} \mathrm{C}(1)$ and $1100{ }^{\circ} \mathrm{C}(2)$

Ti-6Al-4V Alloy. Typical engineering stress-strain curves of $\mathrm{Ti}-6 \mathrm{Al}-4 \mathrm{~V}$ alloy were characterized by sharp transition from elastic to plastic deformation (Fig. 3) that is not typical for this alloy obtained by VAR melting [2, 29]. Af-

ter $\alpha+\beta$ annealing (Fig. 1, $b$ ), the material had better combination of strength and ductility (Fig. 3,a) as compared to annealing in the single phase $\beta$-field (Fig. $3, b$ ) which resulted to coarse-grained lamellar microstructure (Fig. 1, c). Increase in strain rate led to reduction of elongation for both structural conditions, but, in the latter case of coarsegrained lamellar microstructure, this reduction was bigger. After SRHT, the material was not tensile tested because it was impossible to machine cylindrical samples adequately to obtain symmetrical two-layered material. However, in the earlier works, it was shown that surface treatment of this alloy allows improving tensile properties up to the level similar to that after bulk rapid heat treatment when tested with some standard tension rate [27].

Calculated dependences of $U_{\mathrm{D}}$ on tensile strain for different strain rates (Fig. 4) showed essential difference between these two structural states. First, it should be underlined that, in the material annealed at the temperatures of two-phase field, the $U_{\mathrm{D}}$ value was higher and had less pronounced dependence on strain rate as compared to the alloy annealed in the single-phase field.

Ti-1.5Al-6.8Mo-4.5Fe Alloy. The influence of tension rate on mechanical behaviour of this alloy has been studied in detail in our previous works $[20,21,34]$. In the present study, we took as a program material a newly melted by single-melt EBCH alloy which was subjected to hot pressing and rolling as described in Ref. [30]. This program material had specific microstructure features (Fig. 2) and crystallographic texture as compared to earlier studied TIMETAL-LCB alloy of the same composition, but melted by standard VAR technology [2] and subjected to much heavier total deformation. Typical engineering stress-strain curves for our material are presented in Fig. 5. It is interesting to note that, in both principally different conditions-two-phase $\alpha+\beta$ fine globular (Fig. 2, a) and single-phase metastable $\beta$ (Fig. 2, b), this alloy had very similar stress-strain curves at the same strain rates (compare curves 1 and 2 on Fig. 5, $a$, with curves 1 and 3 on Fig. 5, b). This fact 


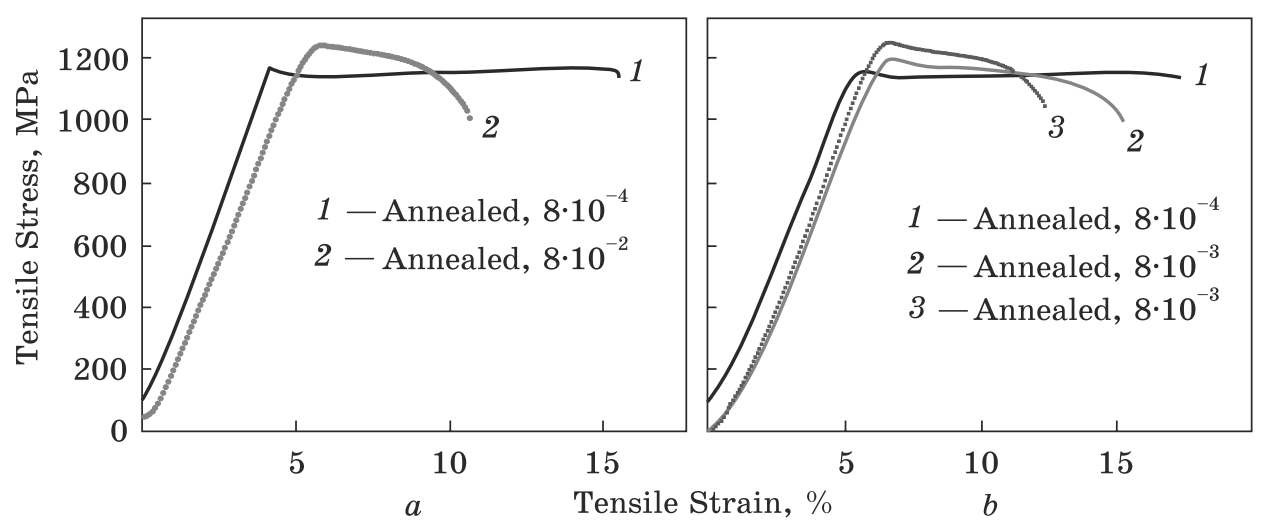

Fig. 5. Typical engineering stress-strain curves of $\mathrm{Ti}-1.5 \mathrm{Al}-6.8 \mathrm{Mo}-4.5 \mathrm{Fe}$ alloy tested at various strain rates in different microstructural states: $a$ - after annealing $750{ }^{\circ} \mathrm{C}$ for $1 \mathrm{~h} ; b-$ after water quenching from $900{ }^{\circ} \mathrm{C}$

Fig. 6. Deformation energy vs. strain rate for $\mathrm{Ti}-1.5 \mathrm{Al}-6.8 \mathrm{Mo}-4.5 \mathrm{Fe}$ alloy in two conditions: 1 - annealed in twophase $\alpha+\beta$-field; $(2-$ quenched from $\beta$-field (metastable single-phase condition)

is unexpected and may be explained by very fine microstructure of the alloy annealed at $750{ }^{\circ} \mathrm{C}$.

The dependences of $U_{\mathrm{D}}$ on strain rate, calculated by tensile curves

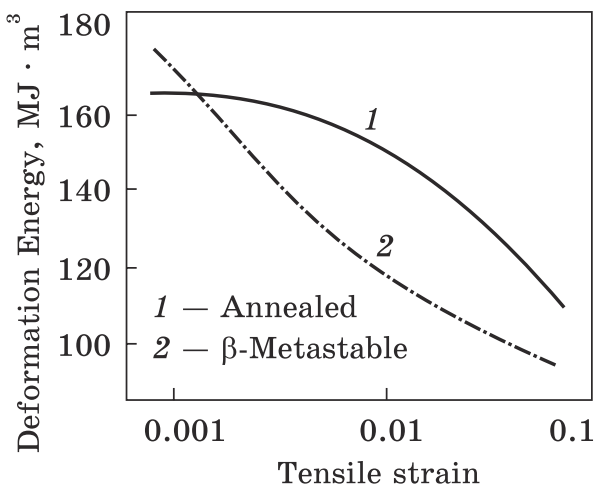
for these two microstructural conditions, are presented in Fig. 6. They also showed similar decrease in deformation energy with deformation rate. Such dependence is rather typical for this alloy [20, 21, 34], and was explained by factors: (i) high density of interphase $\alpha / \beta$ boundaries, which are sites of plastic deformation localization and nucleation of pores and cracks [34, 35] in annealed condition, and (ii) by specific crystallographic texture in metastable condition, as it will be shown later.

A comparison of two materials from the viewpoint of dependences of deformation energy on strain rate allows concluding as follows below. The $\mathrm{Ti}-1.5 \mathrm{Al}-6.8 \mathrm{Mo}-4.5 \mathrm{Fe}$ alloy in both annealed $\alpha+\beta$ and quenched for metastable $\beta$-phase states, despite higher initial (at $10^{-3} \mathrm{~s}^{-1}$ ) levels of $U_{\mathrm{D}}$, is more sensitive to deformation rate as compared to $\mathrm{Ti}-6 \mathrm{Al}-4 \mathrm{~V}$ alloy annealed in the two-phase $\alpha+\beta$ field. 


\section{Three-Point Flexure}

Ti-6Al-4V Alloy. The overviews of specimens after three-point flexural tests are presented in Fig. 7. As seen, the material with coarsegrained lamellar microstructure cracked on earlier stages of plastic deformation (specimens 1 and 2), while, in the specimen with globular microstructure, crack appeared on later stage of plastic flow when deformed at lower bending rate (specimen 3 ).

The flexural stress-strain curves illustrate essential superiority of the material annealed in the two-phase $\alpha+\beta$ field over the coarse-grained lamellar condition in both strength and especially ductility: the laminated microstructure after $\alpha+\beta$ annealing had approximately 6 times larger plastic deformation (compare Fig. 8, $a$ and $b$ ). Gradient microstructure after SRHT (Fig. 1, $d$ ) led to specific changes in flexure properties of the alloy: the curves look like a combination of the first two versionsstrength level approached to the $\alpha+\beta$ annealed condition, while strains were intermediate between these two structural states (Fig. 8, c).

Investigation of microstructure in the zones of intensive plastic deformation allowed clarifying the features of the influence of microstructure on mechanical behaviour during flexural testing (Fig. 9). In the case of coarse-grained lamellar microstructure, main crack propagated from the bottom surface (where tension stress on flexure was maximal) almost normally to this surface with rather small branching (Fig. 9, a). The starting short crack was nucleated and grew initially along a packet of $\alpha$-lamellas (Fig. 9, $b$ ). At further, propagation crack was deviated on boundaries of neighbouring $\alpha$-phase packets with different crystallographic orientations (Fig. 9,c).

At the same time, after annealing at temperature of two-phase field, there were no coarse equiaxed $\beta$-grains and intragrain $\alpha$-lamellas, and the main crack initially grew at an angle of $45^{\circ}$ to the bottom surface and changed the direction of growth when achieved length of approximately $3 \mathrm{~mm}$ (Fig. 9, $d$ ). There was no noticeable effect of microstructure on crack propagation; however, at higher magnifications plenty of pores were observed around crack on the etched surface of the specimens (Fig. 9, $e, f)$. The specimens after SRHT were not completely fractured at maximal bend angle, and cracks stopped at distance of $2-3 \mathrm{~mm}$ from the thermally strengthened layer (Fig. 9, g): final cracks were shorter as
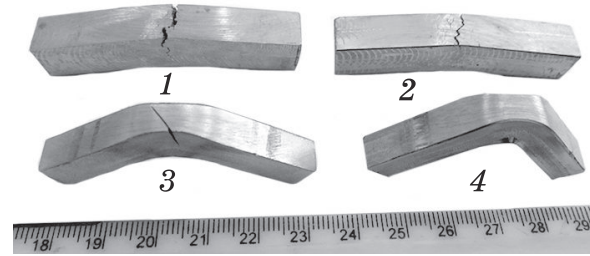

Fig. 7. Overviews of $\mathrm{Ti}-6 \mathrm{Al}-4 \mathrm{~V}$ specimens after $(1,2) \beta$-annealing $\left(1100^{\circ} \mathrm{C}\right.$, $1 \mathrm{~h})$, and $(3,4) \alpha+\beta$ annealing $\left(880^{\circ} \mathrm{C}\right.$, $2 \mathrm{~h})$, tested for three-point bending with rates $(1,3) 10^{-3} \mathrm{~s}^{-1}$ and $(2,4) 10^{-1} \mathrm{~s}^{-1}$ 


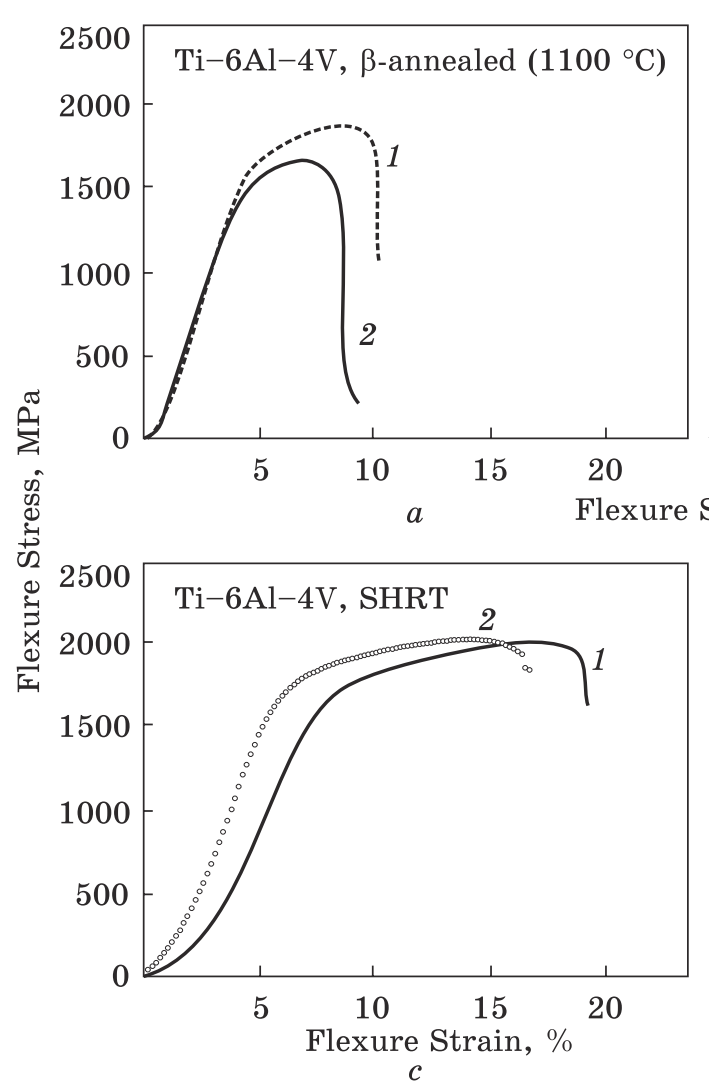

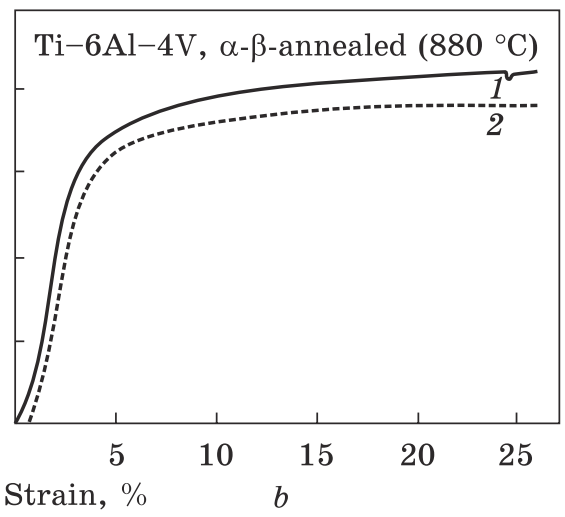

Fig. 8. Flexural stress-strain curves after three-point bending of $\mathrm{Ti}-6 \mathrm{Al}-4 \mathrm{~V}$ specimens after $a-$ annealing at $1100^{\circ} \mathrm{C}$ (coarse-grained lamellar microstructure), $b-$ annealing at $880{ }^{\circ} \mathrm{C}$, and $c-\mathrm{SRHT}$. Flexure rates: $10^{-3} \mathrm{~s}^{-1}$ (1) and $10^{-1} \mathrm{~s}^{-1}(2)$

compared to other structural conditions for the same rates and degrees of deformation. In the 'basic' non-hardened layer, the main crack several times changed direction and propagated mainly along the boundaries of neighbouring $\alpha$-phase packets (Fig. 9, $h$ ), while on the last stage the crack crossed both these packets and individual $\alpha$-lamellas (Fig. 9, $i$ ).

Ti-1.5Al-6.8Mo-4.5Fe Alloy. At higher flexure rate, all $\mathrm{Ti}-1.5 \mathrm{Al}-$ $6.8 \mathrm{Mo}-4.5 \mathrm{Fe}$ specimens, in both $\alpha+\beta$ annealed and as quenched from single $\beta$-phase conditions, were broken on the stage of elastic deformation (Fig. 10). Only metastable $\beta$ specimens tested at lower flexure rate had non-zero ductility; and this behaviour is opposite to $\mathrm{Ti}-6 \mathrm{Al}-4 \mathrm{~V}$ alloy. Investigation of fracture surfaces of annealed specimens allowed distinguishing three separate zones: 1 - crack nucleation and initial growth, 2 - intensive growth zone, and 3 - final fracture (Fig. 11, a). The overview of the first zone (indicated by arrow on Fig. 11, $a, b$ ) revealed that crack appeared in sub-surface layer and initially grew by ductile mechanism. However, when crack length reached about $30 \mu \mathrm{m}$, the character of crack growth changed to a brittle one, and layered fracture surface was observed in this zone ( 2 in Fig. 11, $a$ and $c$ ). 

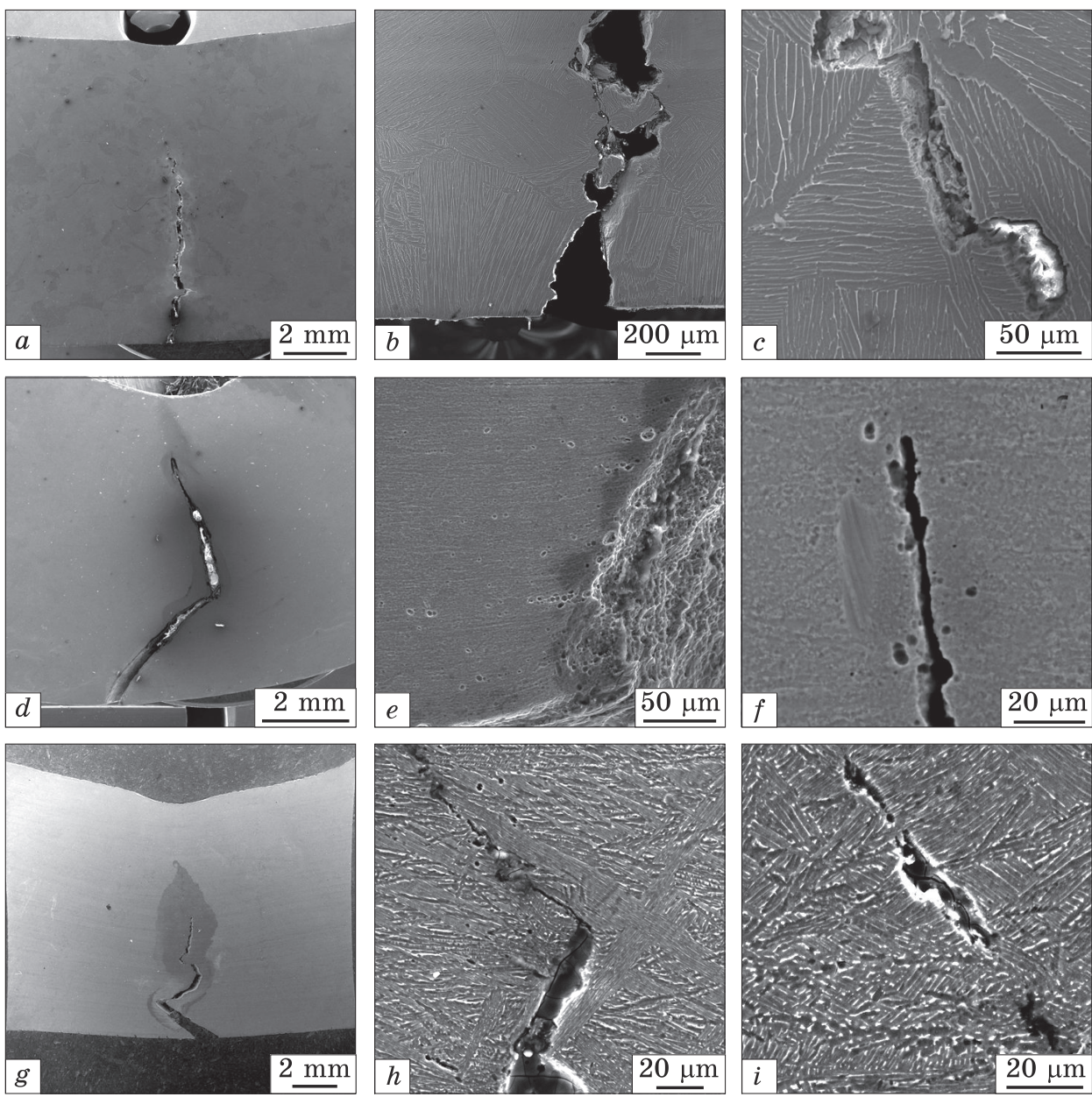

Fig. 9. Microstructure of $\mathrm{Ti}-6 \mathrm{Al}-4 \mathrm{~V}$ alloy after annealing $1 \mathrm{~h}$ at various temperatures and three-point flexural testing: $(a-c) 1100^{\circ} \mathrm{C}$ (coarse-grained lamellar state), $(d-f)-880^{\circ} \mathrm{C}$, and $(g-i)-$ after SRHT. SEM data

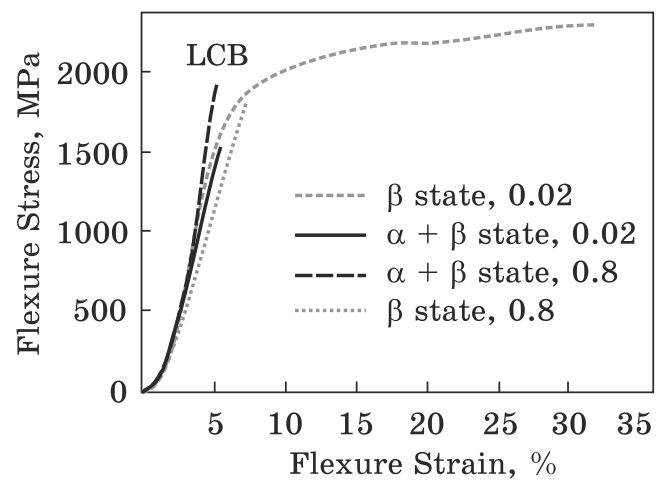

Fig. 10. Flexural stress-strain curves for $\mathrm{Ti}-1.5 \mathrm{Al}-6.8 \mathrm{Mo}-4.5 \mathrm{Fe}$ alloy in $\alpha+$ $+\beta$ annealed and metastable $\beta$ states tested with different rates 

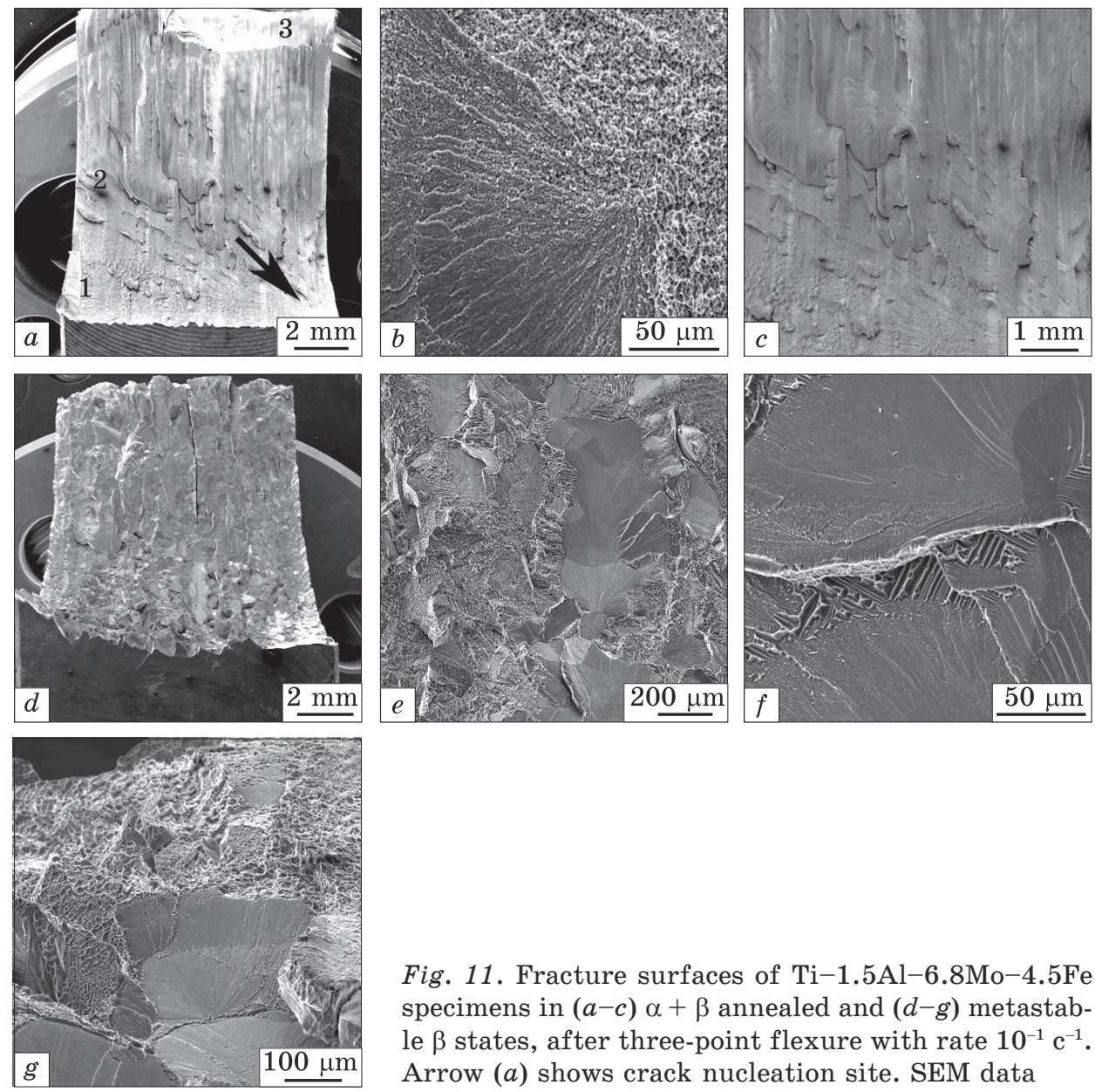

Fig. 11. Fracture surfaces of $\mathrm{Ti}-1.5 \mathrm{Al}-6.8 \mathrm{Mo}-4.5 \mathrm{Fe}$ specimens in $(a-c) \alpha+\beta$ annealed and $(d-g)$ metastable $\beta$ states, after three-point flexure with rate $10^{-1} \mathrm{c}^{-1}$. Arrow $(a)$ shows crack nucleation site. SEM data

Fracture surfaces of the specimens in single-phase metastable $\beta$ state did not have evident signs of crack nucleation sites (Fig. 11, d). Both initial zone of crack growth (perpendicular to the outer surface of specimen) and zone of intensive propagation (parallel one) had the same character characterized by mixture of ductile and brittle (cleavage) areas (Fig. 11, $d$ ) that was earlier observed in this alloy upon tensile tests [34] and explained by specific orientations of $\beta$-grain boundaries relatively to direction of applied tension stress. On the boundaries of cleavage areas (presumably, grain boundaries), a relief similar to lamellar intragrain microstructure was observed (Fig. 11, $f$ ). In the zone of final fracture, character of surface was ductile (Fig. 11, $f$ ).

Summarizing the results of tensile and three-point flexural tests, it is possible to conclude that only $\mathrm{Ti}-6 \mathrm{Al}-4 \mathrm{~V}$ alloy in annealed $\alpha+\beta$ state demonstrated ductile behaviour in both types of tests. This is obviously 
due to comparatively large area of uniform plastic deformation (Figs. 3, $a$, and $8, b$ ), while in another structural condition (Fig. $3, b$ ) this alloy, as well as $\mathrm{Ti}-1.5 \mathrm{Al}-6.8 \mathrm{Mo}-4.5 \mathrm{Fe}$ alloy (Figs. 5 and 10 ) underwent early localization of plastic deformation, that caused much earlier failure.

\section{Ballistic Impact Tests}

Ti-6Al-4V Alloy: $11 \mathrm{~mm}$ Thick Plate. The $11 \mathrm{~mm}$ thick plate of Ti-6Al-4V alloy was subjected to ballistic tests with two types of projectiles, which differed in calibre, mass, state of steel core, speed of bullets, and therefore had different specific kinetic energies (see \#\# 1 and 2 in Table 2). The overviews of tested plates with different microstructural states are shown in Fig. 12. As seen, in as-rolled (without final heat treatment) condition, the plate was pierced by 7.62 calibre LPS bullet, and withstood a bullet of 5.45 calibre (Fig. 12, $a, b$ ). The behaviour of plate annealed at two-phase $\alpha+\beta$ field temperature was very similar (Fig. 12, $c$ and $d$ ), while, after annealing at single-phase $\beta$ temperature (with resulting coarse-grained lamellar microstructure,
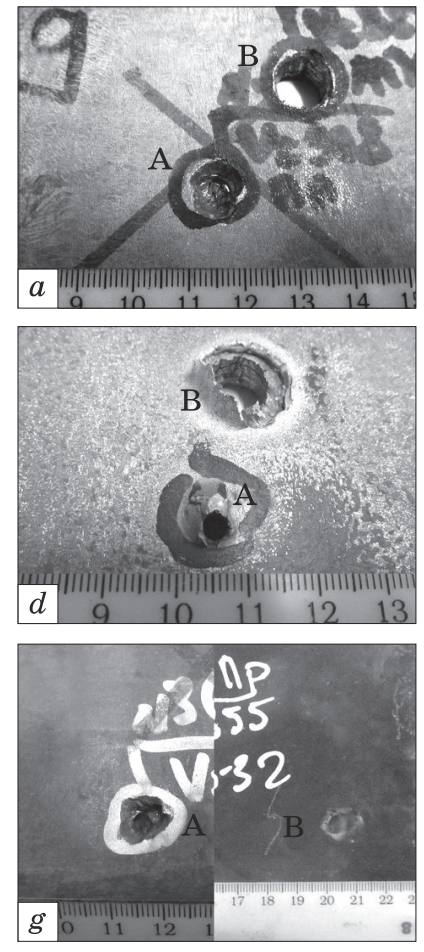
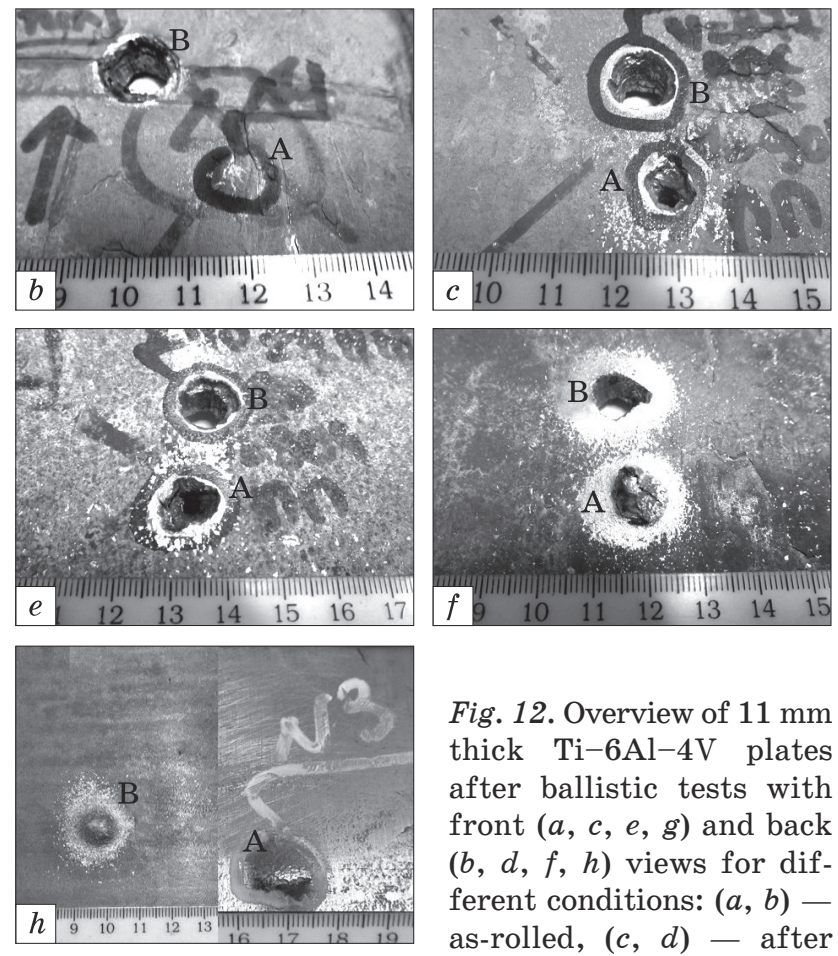

Fig. 12. Overview of $11 \mathrm{~mm}$ thick $\mathrm{Ti}-6 \mathrm{Al}-4 \mathrm{~V}$ plates after ballistic tests with front $(a, c, e, g)$ and back $(b, d, f, h)$ views for different conditions: $(a, b)-$ as-rolled, $(c, d)$ - after

$\beta$-annealing at $1100^{\circ} \mathrm{C}$ for $1 \mathrm{~h},(e, f)-$ after $\alpha+\beta$ annealing at $880^{\circ} \mathrm{C}$ for $2 \mathrm{~h}$, and $(g, h)$ - after SRHT (surface strengthening). Here, front $(a, c, e, g)$ and back $(b, d$, $f, h)$ - views are presented. $A$ - results of impact by bullets \#1, $B$ - results of impact by bullets \# 2 

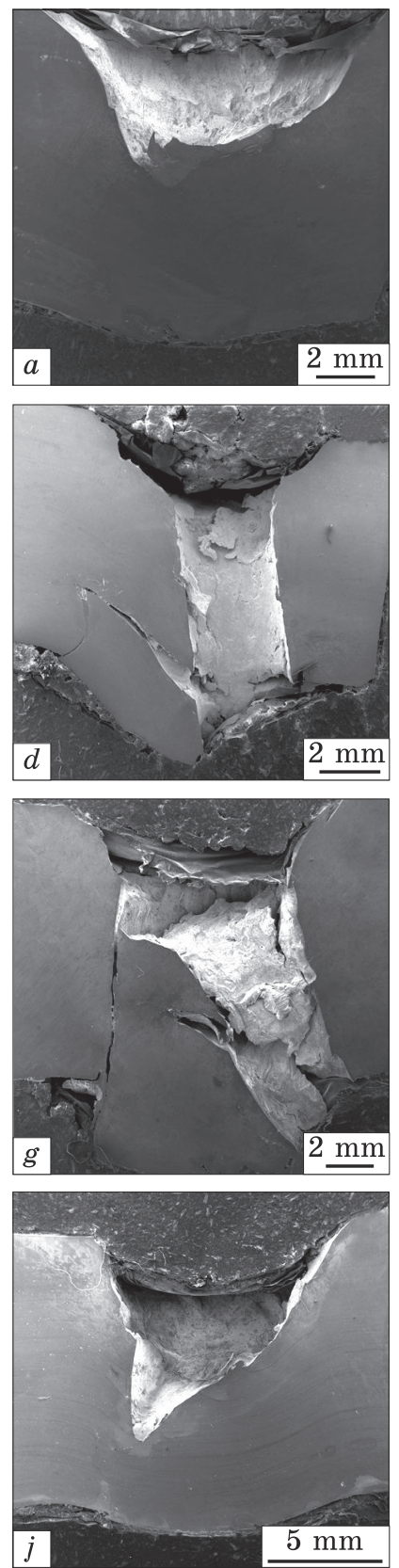
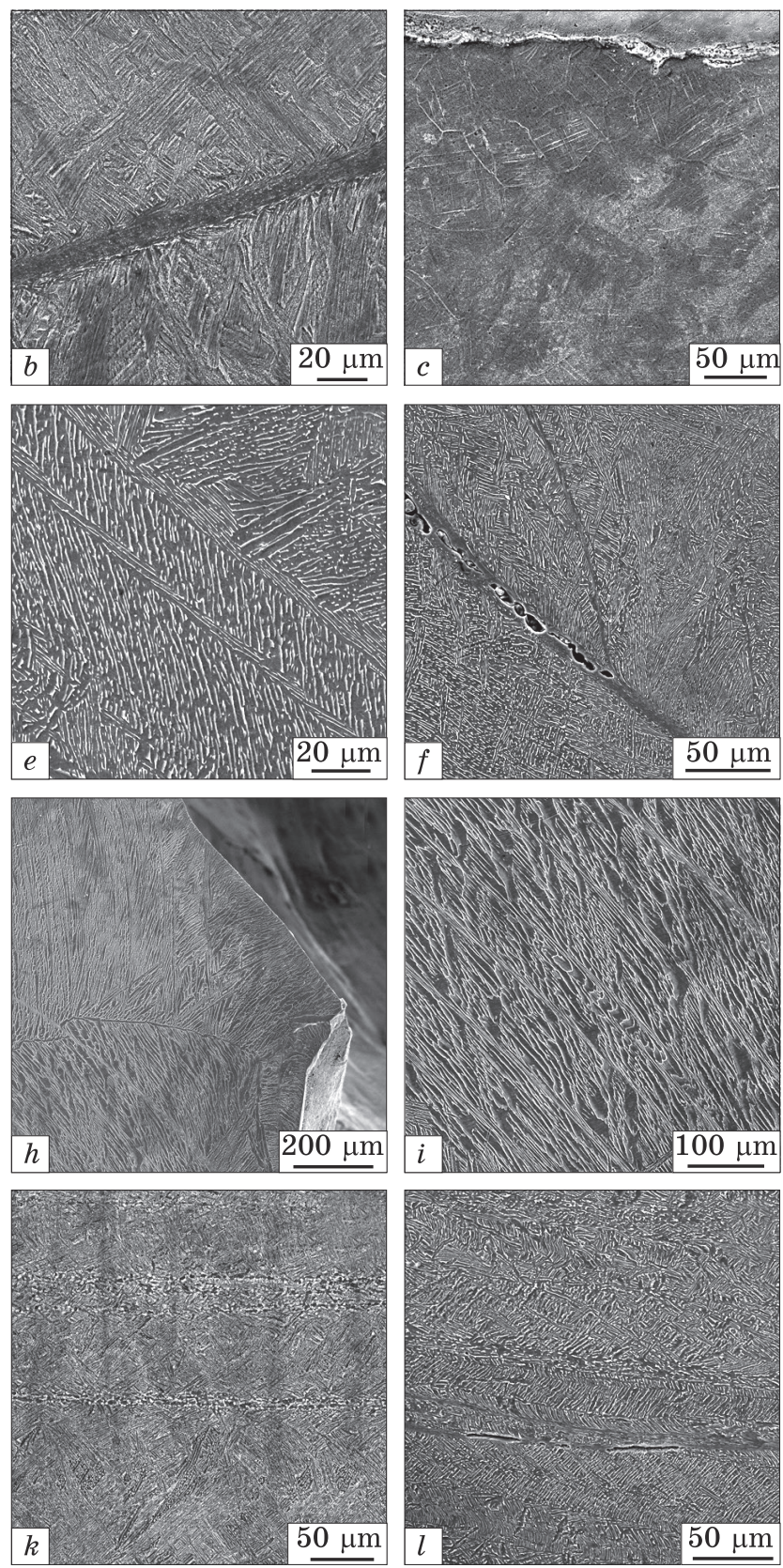

Fig. 13. SEM images for half sections of shot targets $(a, d, g, j)$ and typical microstructure of $\mathrm{Ti}-6 \mathrm{Al}-4 \mathrm{~V}$ alloy $(11 \mathrm{~mm}$ thick plate) after ballistic tests: $(a-c)-$ as rolled, $(d-f)$ - annealed at $880^{\circ} \mathrm{C}$ for $1 \mathrm{~h},(g-i)$ - annealed at $1100{ }^{\circ} \mathrm{C}$, and $(j-l)-$ after SRHT. PP bullets (\#1 in Table 2) 

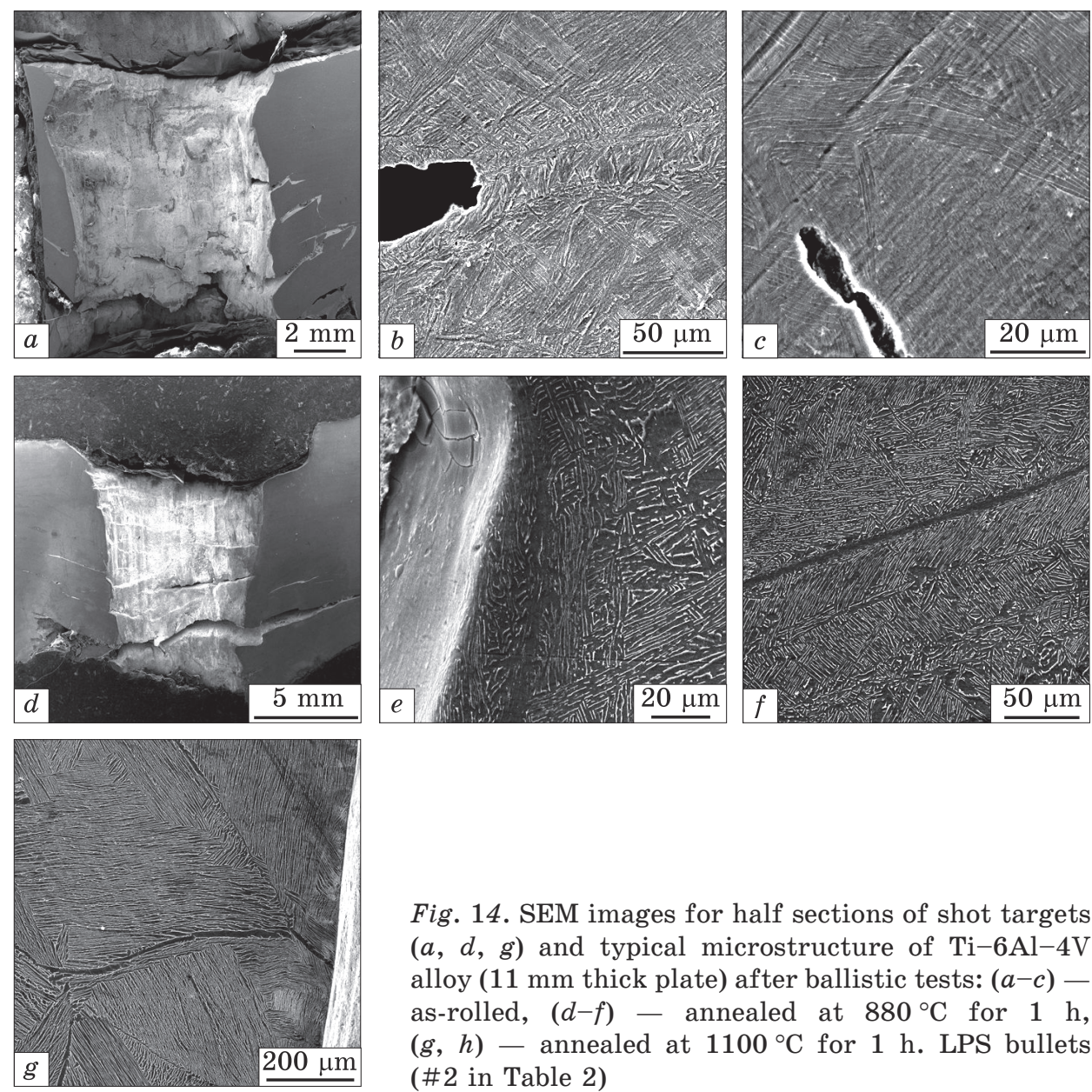

Fig. 14. SEM images for half sections of shot targets $(a, d, g)$ and typical microstructure of $\mathrm{Ti}-6 \mathrm{Al}-4 \mathrm{~V}$ alloy (11 $\mathrm{mm}$ thick plate) after ballistic tests: $(a-c)-$ as-rolled, $(d-f)$ - annealed at $880^{\circ} \mathrm{C}$ for $1 \mathrm{~h}$, $(g, h)$ - annealed at $1100{ }^{\circ} \mathrm{C}$ for $1 \mathrm{~h}$. LPS bullets (\#2 in Table 2)

Fig. 1, c), the plate was pierced by bullets of both types (Fig. 12, $e, f$ ). In other words, $11 \mathrm{~mm}$ thick plates of $\mathrm{Ti}-6 \mathrm{Al}-4 \mathrm{~V}$ alloy with both laminated microstructural states showed rather good resistance against penetration of bullets with average specific kinetic energy $\approx 65 \mathrm{~J} / \mathrm{mm}^{2}$, and could not stand against bullets with energy $\approx 78 \mathrm{~J} / \mathrm{mm}^{2}$. At the same time, the plate with $\beta$-transformed coarse-grained lamellar microstructure was not able to resists against even bullets with lower energy.

The most promising result for $11 \mathrm{~mm}$ thick plate was obtained in as-rolled condition with subsequent special SRHT; this plate was not pierced by both types of bullets (Fig. 12, $g$ and $h$ ) that is in a good agreement with the results of three-point flexure tests (Figs. 8, $c$, and 9, $h, i$ ). In other words, the surface strengthening treatment allows obtaining a condition with higher ballistic resistance, and the present results are apparently better than the data obtained in J. Fanning's work [9]. The 

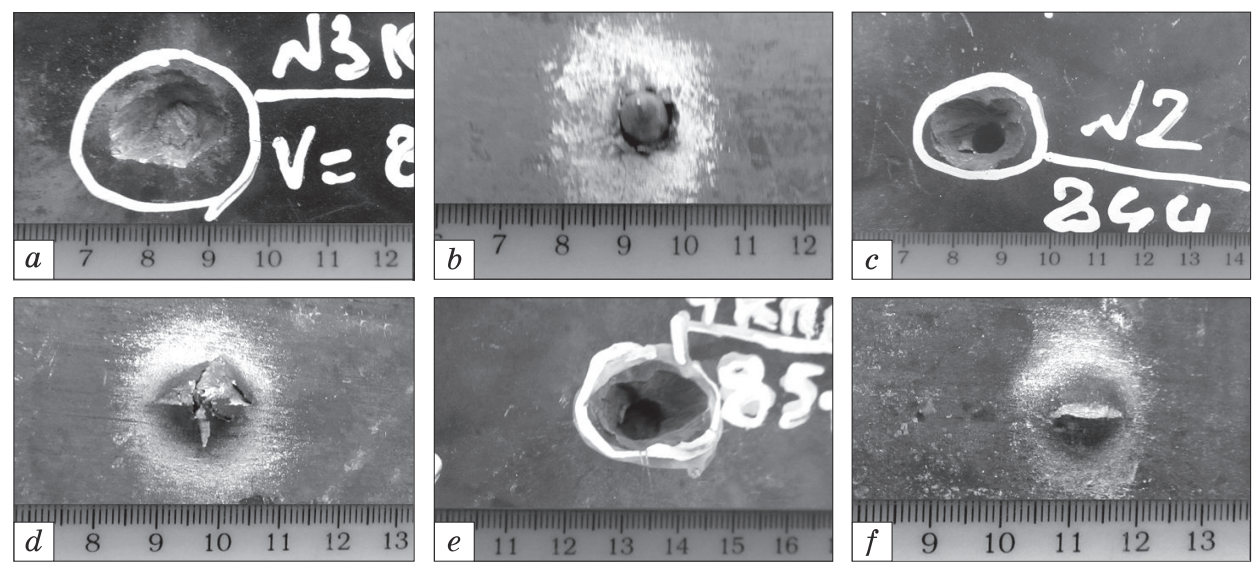

Fig. 15. Overview of $\mathrm{Ti}-6 \mathrm{Al}-4 \mathrm{~V}$ alloy ( $23 \mathrm{~mm}$ thick plates) after ballistic tests with projectile \#3 (Table 2, bullets B-32) for different conditions: $(a, b)-$ after $\beta$-annealing at $1100{ }^{\circ} \mathrm{C}$ for $\left.1 \mathrm{~h}\right),(c, d)-$ after $\alpha+\beta$ annealing at $880^{\circ} \mathrm{C}$ for $2 \mathrm{~h}$, and $(e, f)$ - after SRHT

peculiarities of plastic flow were studied on the sections cut from the sites impacted by bullets (Fig. 13).

In the as-rolled specimen (Fig. 13, a), separate adiabatic shear bands (ASB) with thickness of about 10-12 $\mu \mathrm{m}$ were observed on the lateral sides of the bullet channel (Fig. 13, b), while, in the lower part of the crater, a $\beta$-transformed microstructure was found (Fig. 13, $c$; the depth of this $\beta$-transformed layer was about $2 \mathrm{~mm}$ ). This may be explained by intensive local heating of the material above beta-transus, i.e. an essential part of kinetic energy transformed into a heat. Annealing at the temperature of $\alpha+\beta$ field made material 'weaker'; it was pierced by this type of projectile (Fig. 13, $d$ ). Several ASB were observed near the middle section of the bullet channel (Fig. 13,e), and, in some places, pores appeared inside the ASBs (Fig. 13, f). After annealing at the temperature of $\beta$-field, the material was also pierced, and coarse cracks appeared around the bullet channel where the bullet punched material (Fig. 13, g). In upper part of the channel, no evidences of plastic deformation were found (Fig. 13, h), while, in the bottom zone, multiple ASBs inclined at an angle of more than $45^{\circ}$ were observed (Fig. 13, i). After SRHT, the plate was not pierced by bullet (Fig. 13, j), and ASBs parallel to the surface were found near the middle section of the channel (Fig. 13, k) as well as in the 'deep bottom' — on the distance more than $3 \mathrm{~mm}$ from the channel tip (Fig. 13, l).

Figure 14 illustrates similar features of plates' microstructures after shooting by LPS bullets (\#2 in Table 2). First of all, it should be mentioned that all microstructures (except after surface strengthening by SRHT) were pierced by this relatively high-energy projectile (see 

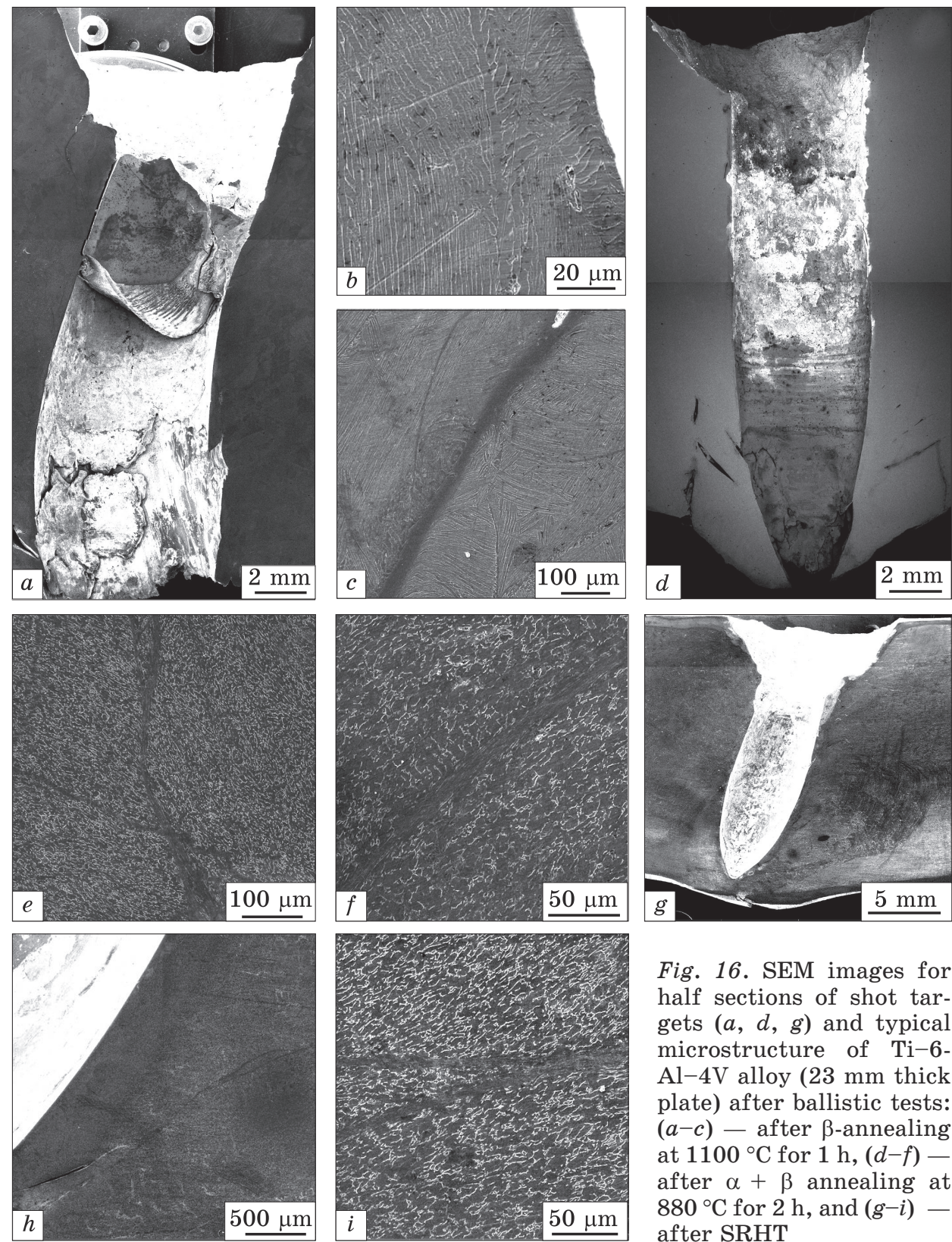

Fig. 16. SEM images for half sections of shot targets $(a, d, g)$ and typical microstructure of $\mathrm{Ti}-6$ $\mathrm{Al}-4 \mathrm{~V}$ alloy $(23 \mathrm{~mm}$ thick plate) after ballistic tests: $(a-c)-$ after $\beta$-annealing at $1100{ }^{\circ} \mathrm{C}$ for $1 \mathrm{~h},(d-f)-$ after $\alpha+\beta$ annealing at $880^{\circ} \mathrm{C}$ for $2 \mathrm{~h}$, and $(g-i)$ after SRHT

Table 1), and bullet channels looked like punching out a 'cork' (Fig. 14, $a, d, g)$. Due to high localization of plastic deformation, the flow occurred in the material adjacent to the bullets channels, that led to the formation of cracks (Fig. 14, b, c), and only in some cases ASBs were observed (Fig. 14, f). Besides, it should be mentioned that, in most duc- 

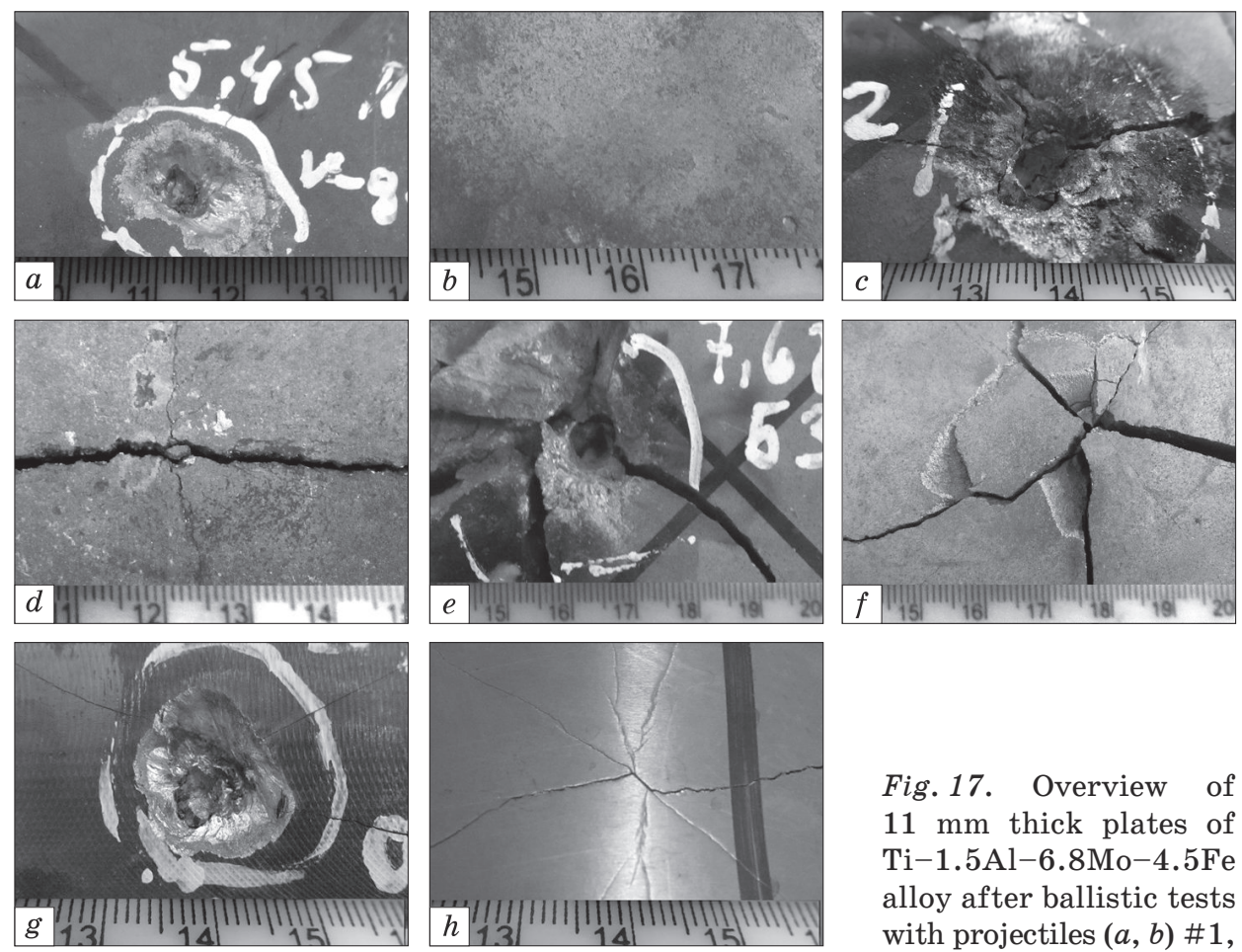

Fig. 17. Overview of $11 \mathrm{~mm}$ thick plates of $\mathrm{Ti}-1.5 \mathrm{Al}-6.8 \mathrm{Mo}-4.5 \mathrm{Fe}$ alloy after ballistic tests with projectiles $(a, b) \# 1$,

$(c, d, g, h) \# 2$, and $(e, f) \# 3$ for two conditions: $(a-f)-$ after $\alpha+\beta$ annealing at $750{ }^{\circ} \mathrm{C}$ for $2 \mathrm{~h}$ and $(g, h)$ - after SRHT strengthening

tile condition (after annealing at $\alpha+\beta$ temperature), some traces of plastic flow were found close to the bullet channel (Fig. 14,e), while, in less ductile one (after annealing at $\beta$-temperature; Fig. 14, $h$ ), fracture took place without any visible changes in microstructure. At the same time, in SRHT-treated plate, which was not pierced (Fig. 12, $g, h$ ), the traces of deformation were similar to those observed for projectile \#1 (Fig. 13, $k, l)$.

Ti-6Al-4V Alloy: 23 mm Thick Plate. The overviews of specimens shot with projectiles B-32 are shown in Fig. 15. As seen, the material after annealing at the temperature of single-phase $\beta$-field with coarsegrained lamellar microstructure was completely pierced, and the bullet was stuck in the plate (Fig. 15, $a, b$ ). In two other structural states after annealing at $\alpha+\beta$ temperature (Fig. 15, $c, d$ ) and after SRHT (Fig. 15, $e, f)$, the plates were not penetrated through, and the 'bulge' effect was noticeably less pronounced in the case of SRHT. These observations are in a good agreement with the results obtained for $11 \mathrm{~mm}$ thick material after the same treatments, and they confirm the positive influence of both annealing at temperatures below the $\beta$-transus and surface strengthening treatment. 

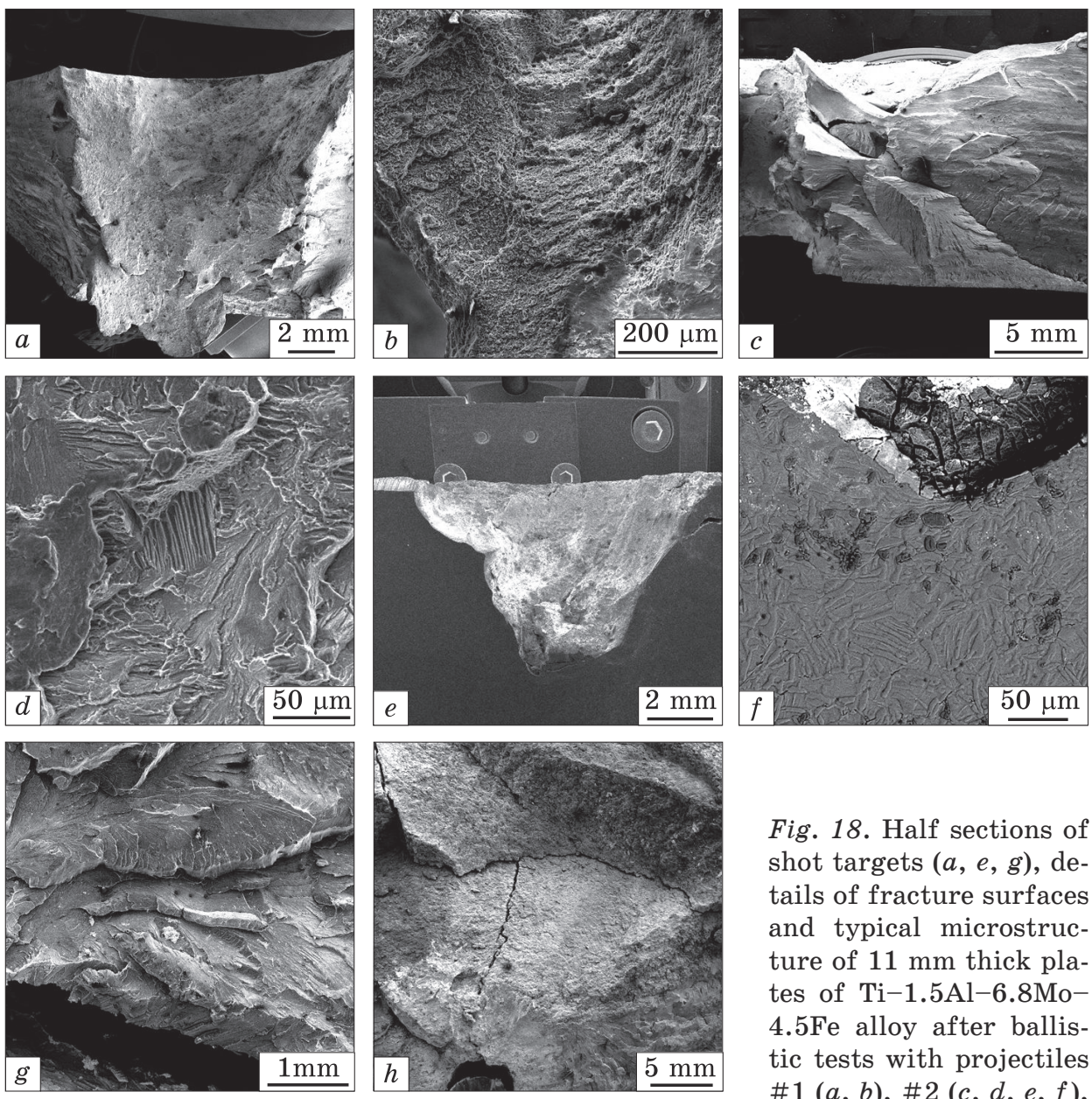

Fig. 18. Half sections of shot targets $(a, e, g)$, details of fracture surfaces and typical microstructure of $11 \mathrm{~mm}$ thick plates of $\mathrm{Ti}-1.5 \mathrm{Al}-6.8 \mathrm{Mo}-$ $4.5 \mathrm{Fe}$ alloy after ballistic tests with projectiles \#1 $(a, b)$, \#2 $(c, d, e, f)$, and \#3 $(g, h)$ for two conditions: after $\alpha+\beta$ annealing at $750{ }^{\circ} \mathrm{C}$ for $2 \mathrm{~h}(a-d)$ and after SRHT strengthening $(e-h)$. Here, the SEM data are presented

In more detail, the microstructure of the plates near the bullet channels is shown in Fig. 16. After annealing at $1100{ }^{\circ} \mathrm{C}$, the material with coarse-grained lamellar microstructure was punched through (Fig. $16, a)$. There were no noticeable traces of plastic deformation near the edges of bullet channel (Fig. 16, b); separate ASBs were found near the bottom of the channel (where the bullet has already lost most of its energy), and these ASBs end by surface cracks (Fig. 16, $c$ ).

After annealing in two-phase $\alpha+\beta$ field, the material had another type of $\beta$-grain structure and was also pierced through; however, the bullet was completely stopped inside the plate (Fig. 16, $d$ ). Near the top of the bullet channel, some deformation traces were found (Fig. 16,e), and, in the bottom, ASBs and cracks were present as well (Fig. 16, f). 

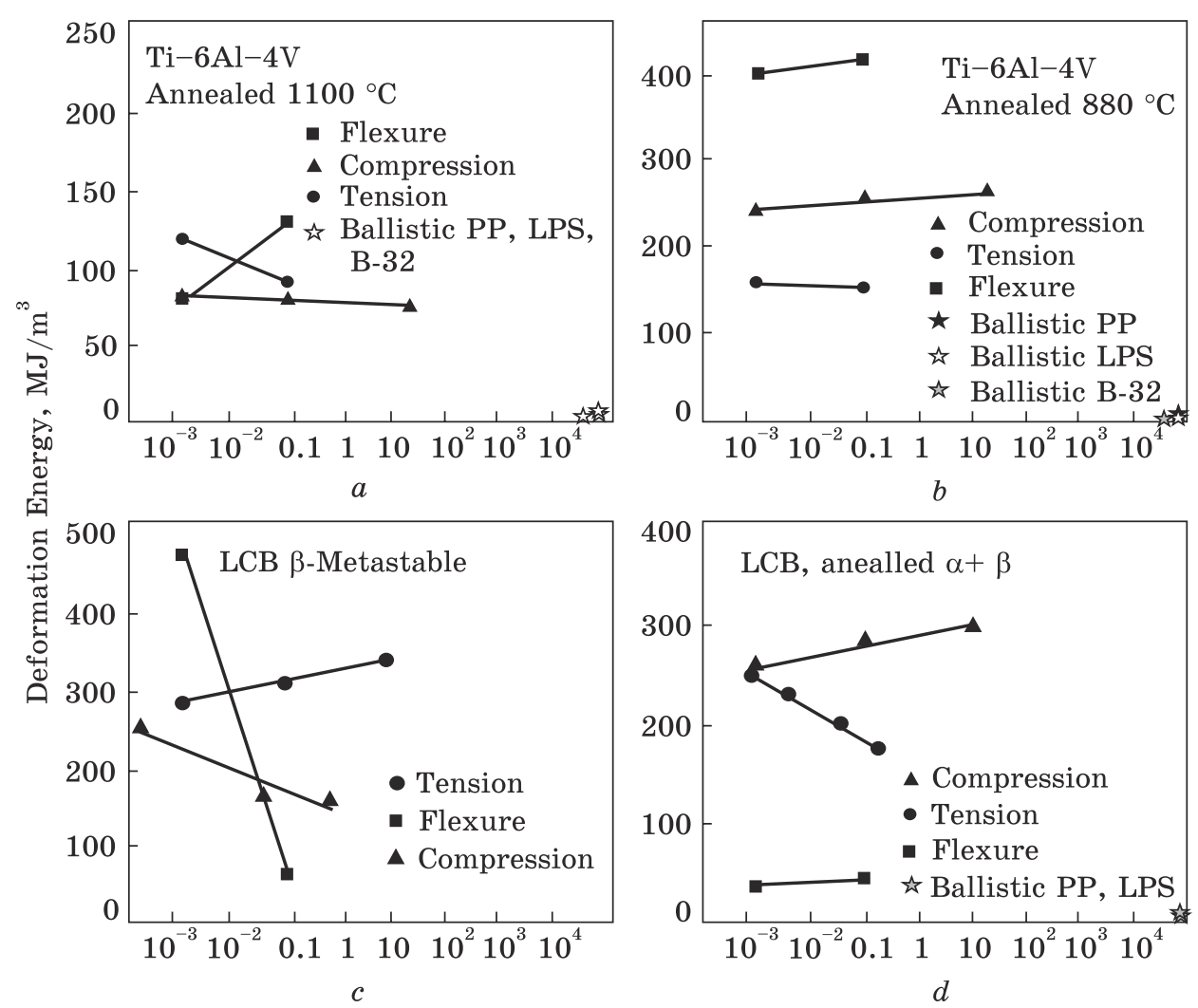

Deformation Rate, $\mathrm{s}^{-1}$

Fig. 19. Deformation energy vs. deformation rate at different types of tests for $a-$ $\mathrm{Ti}-6 \mathrm{Al}-4 \mathrm{~V}$ annealed at temperature of single-phase $\beta$ field, $b-\mathrm{Ti}-6 \mathrm{Al}-4 \mathrm{~V}$ annealed at temperature of two-phase $\alpha+\beta$ field, $c-\mathrm{Ti}-1.5 \mathrm{Al}-6.8 \mathrm{Mo}-4.5 \mathrm{Fe}$ quenched from temperature of single-phase $\beta$ field (fine-grained metastable $\beta$ state), $d-$ $\mathrm{Ti}-1.5 \mathrm{Al}-6.8 \mathrm{Mo}-4.5 \mathrm{Fe}$ annealed at temperature of two-phase $\alpha+\beta$ field. Data for compression tests were taken from [23]. Open 'star' symbols on $(a, b)$ indicate results with complete piercing of plates. Solid 'star' symbols $(b, d)$ indicate results of ballistic tests without piercing

After SRHT, the bullet did not penetrate through the plate, and a bulge of about 2-2.5 mm height formed on the rear side (Fig. 16, g). The ASBs were observed both on the top (Fig. 16, $h$ ) and bottom (Fig. 16, $i$ ) sections that indicates on the localization of plastic flow in both top (thermally hardened) and bottom (ductile) layers. In other words, hardened by SRHT, layer had relatively good reserve of general ductility, despite its higher strength, and its level of ductility was rather close to that of the material annealed at temperatures of $\alpha+\beta$ field, whereas the alloy with coarse-grained lamellar microstructure had too low properties. 
Ti-1.5Al-6.8Mo-4.5Fe. Typical examples of $11 \mathrm{~mm}$ thick plates of alloy $\mathrm{Ti}-1.5 \mathrm{Al}-6.8 \mathrm{Mo}-4.5 \mathrm{Fe}$ in different microstructural states after ballistic tests are presented in Fig. 17. First of all, it should be underlined that, after annealing in two-phase $\alpha+\beta$ field, the material was not punched through by bullets of \#1 type, however, some surface cracks appeared (Fig. 17, $a$ and $b$ ), while higher specific kinetic energies (bullets \#2 and \#3) caused cracking (Fig. 17, $c-f$ ). Application of SRHT allowed somewhat to improve ballistic resistance of the alloy against projectiles \#2 (Fig. 17, $g$ and $h$ ), whereas bullets \#3 still punched through the plates.

In more detail, the fracture surfaces of the plates after ballistic tests are shown in Fig. 18. After annealing in $\alpha+\beta$ field and impact by projectile \#1, the bullet channel had relatively ductile relief (Fig. 18, $a$, $b$ ), while impact by more powerful projectile \#2 led to completely brittle fracture (Fig. 18, $c$ and $d$ ). Another situation was observed in specimens after SRHT: despite impact with projectile \#2 also led to brittle fracture (Fig. 19, $g$ and $h$ ), projectile \#1 caused only crater in the surface strengthened layer (Fig. 18, $e$ and $f$ ).

\section{Discussions}

Under three-point flexure, the upper part of sample (where bending force is applied) is compressed and the opposite side is stretched, with a zero-load point located approximately in the middle between them. Hence, in the first approximation, we can assume that this type of test is a combination of stretching and compression tests. Thus, it can be assumed that the energy of deformation $U_{\mathrm{D}}$, which is spent on the threepoint bend, should be approximately equal to the sum of these energies for two tests-tension and compression. Experimental data for compression, obtained with the same program materials, were taken from the work [24]. The dependences of $U_{\mathrm{D}}$ on deformation rate for the same materials and different methods of tests are represented in Fig. 19.

As can be seen from Fig. 19, this assumption is rather accurate for the case of $\mathrm{Ti}-6 \mathrm{Al}-4 \mathrm{~V}$ annealed in two-phase $\alpha+\beta$ field $\left(880^{\circ} \mathrm{C}\right.$, Fig. 19 , $a$ ). It should be also mentioned that similar situation was observed in the same alloy with globular type of microstructure, and in commercial purity titanium regardless of microstructure [26]. At the same time, $\mathrm{Ti}-6 \mathrm{Al}-4 \mathrm{~V}$ and $\mathrm{Ti}-1.5 \mathrm{Al}-6.8 \mathrm{Mo}-4.5 \mathrm{Fe}$ alloys annealed in single-phase $\beta$-filed (coarse-grained lamellar microstructure) have different behaviour (Fig. 19, $b-d$ ). Earlier in [26], this fact was explained by the influence of other factors, including structural and crystallographic texture. Also, as it was established in Ref. [21], lamellar or needle-like $\alpha$-particles play an important role in mechanical behaviour of titanium alloys deformed with different rates, because their tips are places where defor- 
mational defects concentrate during plastic flow, leading to the formation of pores and then cracks.

Another moment to be emphasized is the following: $\mathrm{Ti}-1.5 \mathrm{Al}-$ $6.8 \mathrm{Mo}-4.5 \mathrm{Fe}$ in metastable single-phase $\beta$-condition had high ductility that resulted in high $U_{\mathrm{D}}$ values under tension and compression, while for three-point flexure this parameter was rather high only for relatively slow deformation rate (Fig. 19,c). Perhaps, this is a result of probable decomposition of metastable $\beta$-phase during the complex mode of deformation (and possible precipitation of embrittling particles of $\omega$-phase, especially, taking into account local heating inside ASBs formed at high deformation rates). Regarding this alloy in the two-phase $\alpha+\beta$ state, $U_{\mathrm{D}}$ values for three-point flexure were much lower than for tensile and compression tests. This is obviously due to the peculiarities of microstructure (the presence of thin lamellar particles of $\alpha$-phase whose tips play above-mentioned role of stress concentrators) and the crystallographic texture formed upon rolling, which may be unfavourably oriented relative to the applied load.

The results of present study and previous data allow us to conclude that the $U_{\mathrm{D}}$ values of investigated alloys generally are determined by their phase composition, microstructure, and structural and crystallographic texture, which, in turn, determine the balance between strength and ductility, and this balance depends on deformation mode and rate too. Thereby, relatively low-alloyed $\mathrm{Ti}-6 \mathrm{Al}-4 \mathrm{~V}$ alloy with globular (equiaxed) microstructure has rather high values of ductility. However, hardening of this alloy by heat treatment cannot ensure high strength; in the best case after special Rapid Heat Treatment (bulk), UTS does not exceed 1300-1350 MPa [22, 27]. At the same time, metastable $\beta$-alloy $\mathrm{Ti}-1.5 \mathrm{Al}-6.8 \mathrm{Mo}-4.5 \mathrm{Fe}$ can be thermally strengthened above $1500 \mathrm{MPa}$, but high content of $\beta$-alloying elements and relatively low beta-transus (temperature of $\alpha+\beta_{0} \rightarrow \beta$ transformation [3]) do not allow to form equiaxed microstructure with $\alpha$-globules of, at least, $2-3 \mu \mathrm{m}$ in diameter and relatively low (as in $\mathrm{Ti}-6 \mathrm{Al}-4 \mathrm{~V}$ alloy) density of interphase $\alpha / \beta$ boundaries which are preferable sites for pore and crack nucleation during plastic flow [21]. These features caused low ductility of thermally strengthened $\mathrm{Ti}-1.5 \mathrm{Al}-6.8 \mathrm{Mo}-4.5 \mathrm{Fe}$ alloy, which may be improved by means of special treatment based on heavy cold deformation followed by rapid recrystallization for forming fine $\beta$-grains (below 5-7 $\mu \mathrm{m}$ ) [22, 36]. Such technological approach was employed for rod materials, but its application for processing of plate material (taking into account the possibility of technological equipment) seems quite problematic. As shown in Refs. [22, 37], the best combination of high strength (above $1800 \mathrm{MPa}$ ) and good ductility can be obtained by rapid heat treatment of such titanium alloy as VT23 (high-alloyed martensitic class alloy), where the content of $\beta$-alloying elements is 'intermediate' between Ti- 
$6 \mathrm{Al}-4 \mathrm{~V}$ and $\mathrm{Ti}-1.5 \mathrm{Al}-6.8 \mathrm{Mo}-4.5 \mathrm{Fe}$. In this case, it is possible to expect that $U_{\mathrm{D}}$ will be higher, including high deformation rates.

Of course, the results of standard mechanical tests are difficult to compare with the results of ballistic ones. Nevertheless, employing such rather versatile parameter as $U_{\mathrm{D}}$ and calculating (with some simplifications) its values for ballistic tests basing on the speed of the bullet, its calibre and the thickness of tested plate, we tried to fulfil this comparison. Though this approach is rather arbitrary, it allows to assess the ballistic resistance of materials considering the relation between $U_{\mathrm{D}}$ values for the same deformation rates obtained in ballistic tests and, if possible, by other standard methods. In other words, if $U_{\mathrm{D}}^{\text {Ballistic }}>$ $>U_{\mathrm{D}}^{\text {Standard }}$, material will be pierced, and if $U_{\mathrm{D}}^{\text {Ballistic }}<U_{\mathrm{D}}^{\text {Standard }}$, material will resist against ballistic impact. An attempt to make such a comparison is presented in Fig. 19, $a, b, d$, where the results of ballistic tests are plotted by 'star' symbols. First of all, it should be noted that an increase in strain rate by four orders of magnitude reduces $U_{\mathrm{D}}$ levels also by several orders. Despite the significant difference between $U_{\mathrm{D}}$ levels of studied alloys at low deformation rates, at rates $8 \cdot 10^{4}-8.2 \cdot 10^{4}$ (these values were calculated for ballistic tests), deformation energy varied within the narrow range of $5.7-7.4 \mathrm{~J} / \mathrm{mm}^{3}$, and difference between pierced and not pierced microstructural states was also very small. It should be kept in mind that, in this comparison, we did not take into account the influence of all other factors besides kinetic energy (e.g., the different hardness of bullets and test material). By the way, our results showed some superiority of alloys after annealing in two-phase $\alpha+\beta$ field and SRHT over the same materials with $\beta$-transformed lamellar microstructure.

\section{Conclusions}

The obtained results allow drawing the following conclusions.

(1) The studied alloys obtained by EBMCH melting approach with following hot 3D pressing and rolling had better properties (both standard mechanical at all deformation rates and modes, and ballistic impact properties) after annealing at temperatures of two-phase $\alpha+\beta$ field. In this condition, $\mathrm{Ti}-6 \mathrm{Al}-4 \mathrm{~V}$ alloy had microstructure with flat $\beta$ grains elongated in rolling direction and fine $\alpha$-lamellas inside these grains, while $\mathrm{Ti}-1.5 \mathrm{Al}-6.8 \mathrm{Mo}-4.5 \mathrm{Fe}$ alloy had fine globular-type microstructure.

(2) Annealing in single-phase $\beta$-field resulted in coarse-grained lamellar microstructures and led to a significant decrease in all mechanical properties due to essential drop of ductility.

(3) Special SRH-treatment, which formed thermally strengthened surface layer in combination with ductile core, allowed achieving the 
best level of ballistic impact properties as compared to other microstructural conditions studied in the present work.

(4) Good anti-ballistic properties of $\mathrm{Ti}-6 \mathrm{Al}-4 \mathrm{~V}$ alloy can be explained by a unique combination of properties (of about $1000 \mathrm{MPa}$ ) with high reserve of ductility (including high uniform plastic deformation in not-coarse-grained lamellar state). This properties balance can be obtained even after single-melt EBCH melting followed by hot deformation (rolling) without any final annealing. At the same time, $\mathrm{Ti}-1.5 \mathrm{Al}-$ $6.8 \mathrm{Mo}-4.5 \mathrm{Fe}$ alloy, despite of ability to obtain very high strength (not less than $1500 \mathrm{MPa}$ ), is characterized by relatively poor ductility, and first of all, small stage of uniform plastic deformation with early start of localized plastic flow, especially, at increase of deformation rate.

(5) For a higher efficiency of surface hardening treatment in order to form a gradient microstructure with increased anti-ballistic properties, attention should be paid to alloys with an intermediate (between Ti-6Al-4V and LCB alloys) content of alloying elements. These alloys have two benefits: (i) a well-developed globular microstructure can be formed by annealing at $\alpha+\beta$ temperature; (ii) surface rapid heat treatment allows achieving strength levels $\geq 1500 \mathrm{MPa}$.

Acknowledgments. Parts of this work were done within the frames of the projects \#\# III-09-13, 60/13c, and 60/16п funded by the National Academy of Sciences of Ukraine, and supported by the NATO grant G5030 from the Program 'Science for Peace and Security'.

\section{REFERENCES}

1. I. Weiss, R. Srinivasan, P.J. Bania, D. Eylon, and S.L. Semiatin, Advances in the Science and Technology of Titanium Alloy Processing: Proc. Int. Symposium Sponsored by the TMS Titanium and Shaping and Forming Held at the $125^{\text {th }}$ TMS Annual Meeting and Exhibition in Anaheim (California, February 5-8, 1996 ) (Warrendale, PA: TMS: 1997).

2. G. Luetjering and J.C. Williams, Titanium (Berlin: Springer-Verlag: 2007).

3. R.R. Boyer and R.D. Briggs, J. Mater. Eng. Perform., 14, Iss. 6: 681 (2005).

4. L.O. Chirkina, M.B. Lazareva, V.I. Sokolenko, V.S. Okovyt, and V.V. Kalynovsky, Usp. Fiz. Met., 17, No. 4: 343 (2016).

5. A.D. Pogrebnjak, O.M. Ivasishin, and V.M. Beresnev, Usp. Fiz. Met., 17, No. 1: 1 (2016).

6. V.E. Gromov, K.V. Sosnin, Yu.F. Ivanov, and O.A. Semina, Usp. Fiz. Met., 16, No. 3: 175 (2015).

7. See https://boomsupersonic.com.

8. M. Prampolini and Y. Coraboeuf, Ultra-Rapid Air Vehicle and Related Method for Aerial Locomotion: United States Patent No. 9079661B2 (Published July 14, 2015).

9. J. Fanning, J. Mater. Eng. Perform., 14, Iss. 6: 686 (2005).

10. J.S. Montgomery and M.G.Y. Wells, JOM, 53, Iss. 4: 29 (2001).

11. J. Fanning, Proc. of the $11^{\text {th }}$ World Conference on Titanium) (June 3-7, 2007, Kyoto, Japan) (Kyoto: The Japan Institute of Metals: 2007), p. 487.

12. C. Zheng, F. Wang, and X. Cheng, Int. J. Impact Eng., 85: 161 (2015). 
13. M.S. Burins, J.S. Hansen, J.I. Paige, and P.C. Turner, The Effect of ThermoMechanical Processing on the Ballistic Limit Velocity of Extra Low Interstitial Titanium Alloy Ti-6Al-4V (Army Research Laboratory Report ARL-MR-486: July 2000).

14. B.B. Singh, G. Sukumar, A. Bhattacharjee, K.S. Kumar, T.B. Bhat, and A.K. Gogia, Materials and Design, 36: 640 (2012).

15. C. Zheng, F. Wang, X. Cheng, K. Fu, J. Liu, Y. Wang, T. Liu, and Z. Zhu, Mater. Sci. Eng.: A, 608: 53 (2014).

16. K. Sun, X. Yu, C. Tan, H. Ma, F. Wang, and H. Cai, Mater. Sci. Eng.: A, 595: 247 (2014).

17. G. Sukumar, B.B. Singh, A. Bhattacharjee, K.S. Kumar, and A.K. Gogia, Int. J. Impact Eng., 54: 149 (2013).

18. C. Zheng, F. Wang, X. Cheng, J. Liu, K. Fu, T. Liu, Z. Zhu, K. Yang, M. Peng, and D. Jin, Int. J. Impact Eng., 85: 161 (2015).

19. T.L. Jones, Ballistic Performance of Titanium Alloys: Ti-6Al-4V Versus Russian Titanium (Army Research Laboratory Report ARL-CR-0533: February 2004).

20. P.E. Markovsky, V.I. Bondarchuk, and O.M. Herasymchuk, Mater. Sci. Eng.: A, 645: 150 (2015).

21. P.E. Markovsky and V.I. Bondarchuk, J. Mater. Eng. Perform., 26, Iss. 7: 3431 (2017).

22. P.E. Markovsky, Mechanical Behavior of Titanium Alloys under Different Conditions of Loading, Key Eng. Mater., 2018 (in press).

23. J.S. Montgomery, M.G.H. Wells, B. Roopchand, and J.W. Ogilvy, JOM, 49, Iss. 5: 45 (1997).

24. J.S. Montgomery and M.G.H. Wells, JOM, 53, Iss. 4: 29 (2001).

25. P.E. Markovsky and S.L. Semiatin, J. Mater. Process. Technol., 210, Iss. 3: 518 (2010).

26. P.E. Markovsky, Key Eng. Mater., 436: 185 (2010).

27. P.E. Markovsky and S.L. Semiatin, Mater. Sci. Eng.: A, 528, Iss. 7-8: 3079 (2011).

28. S.V. Akhonin, V.A. Berezos, A.N. Pikulin, A.Yu. Severin, and A.G. Yerokhin, Sourem. Elektrometall., No. 1: 10 (2017) (in Russian).

29. A.N. Kalinyuk, N.P. Trigub, V.N. Zamkov, O.M. Ivasishin, P.E. Markovsky, R.V. Teliovich, and S.L. Semiatin, Mat. Sci. Eng.: A, 346, Iss. 1-2: 178 (2003).

30. S.V. Akhonin, P.E. Markovsky, V.A. Berezos, O.O. Stasyuk, and A.Yu. Severin, Sovrem. Elektrometall., No. 1: 9 (2018) (in Russian).

31. See https://www.imp.kiev.ua/download/development/MVI_1884.MOV.

32. O.M. Ivasishin and P.E. Markovsky, JOM, 48, Iss. 7: 48 (1996).

33. O.M. Ivasishin, P.E. Markovsky, Yu.V. Matviychuk, and P. Allen, Proc. of the $9^{\text {th }}$ World Conf. Titanium'99: Science and Technology (St.-Petersburg, Russia, CRISM 'Prometey': 2000), vol. 1, p. 505.

34. P.E. Markovsky, V.I. Bondarchuk, and Yu.V. Matviychuk, Mater. Sci. Eng.: A, 559: 782 (2013).

35. P.E. Markovsky, V.I. Bondarchuk, O.V. Shepotinnyk, and I.M. Gavrysh, Metallofiz. Noveishie Tekhnol., 38, No. 7: 935 (2016).

36. Q.V. Viet, A.A. Gazder, P.E. Markovsky, A.A. Saleh, O.M. Ivasishin, and E.V. Pereloma, J. Alloys and Compounds, 585: 245 (2014).

37. P.E. Markovsky, Metallofiz. Noveishie Tekhnol., 31: 511 (2009).

Received July 10, 2018; in final version, July 26, 2018 
О.М. Івасишин ${ }^{1}$, С.В. Ахонін ${ }^{2}$, Д.Г. Саввакін ${ }^{1}$, В.О. Березос ${ }^{2}$,

B.I. Бондарчук ${ }^{1}$, О.О. Стасюк ${ }^{1}$, П.Є. Марковський ${ }^{1}$

${ }^{1}$ Інститут металофізики ім. Г. В. Курдюмова НАН України, бульв. Академіка Вернадського, 36, 03142 Київ, Україна

${ }^{2}$ Інститут електрозварювання ім. Є. О. Патона НАН України, вул. Казимира Малевича, 11, 03150 Київ, Україна

\section{ВПЛИВ МІКРОСТРУКТУРИ, СПОСОБУ ТА ШВИДКОСТИ ДЕФОРМАЦІЇ НА МЕХАНІЧНУ ПОВЕДІНКУ СТОПІВ Ti-6Al-4V I Ti-1,5Al-6,8Mo-4,5Fe, ВИГОТОВЛЕНИХ ЕЛЕКТРОННО-ПРОМЕНЕВИМ ТОПЛЕННЯМ}

На прикладі двох промислових економно леґованих титанових стопів, - малолегованого $\alpha+\beta$-стопу Ti-6 Al-4V (мас.\%) і метастабільного $\beta$-стопу Ti-1,5Al$6,8 \mathrm{Mo}-4,5 \mathrm{Fe},-$ виготовлених одноразовим електронно-променевим топленням 3 проміжною ємністю, вивчено вплив формованої за подальших (термомеханічного та термічного) оброблянь мікроструктури на механічну поведінку (виражену через енергію деформації $U_{\mathrm{D}}$ ) при випробуваннях з різними швидкостями деформації та балістичну стійкість. Встановлено, що найменша залежність $U_{\mathrm{D}}$ від швидкости деформації відповідає стопу $\mathrm{Ti}-6 \mathrm{Al}-4 \mathrm{~V}$, відпаленого за температури двофазної $\alpha+\beta$-области, в той час як цей же стоп із пластинчастою мікроструктурою (після відпалювання в однофазній $\beta$-області), як і стоп $\mathrm{Ti}-1,5 \mathrm{Al}-6,8 \mathrm{Mo}-$ $4,5 \mathrm{Fe}$ у різних структурних станах, характеризується інтенсивним пониженням величини $U_{\mathrm{D}}$ з ростом швидкости деформації. Окрім того, тільки відпалений за температури двофазної $\alpha+\beta$-области матеріял після випробувань на триточковий вигин характеризувався тим, що для кожної швидкости деформації величина $U_{\mathrm{D}}$ дорівнювала сумі аналогічних характеристик, одержаних випробуваннями на розтягання та стискання. При наступних балістичних випробуваннях пластин цих стопів різної товщини було встановлено, що найліпша балістична стійкість відповідає матеріялам, які характеризуються великими значеннями $U_{\mathrm{D}}$ та меншою їі чутливістю до швидкости деформації. Детально обговорюється пошкодження стопів при випробуваннях різних типів з точки зору ймовірних механізмів деформації та руйнування.

Ключові слова: титанові стопи, мікроструктура, механічні властивості, механічна поведінка, швидкості деформації, енергія деформації, балістичні випробування.

О.М. Ивасишин ${ }^{1}$, С.В. Ахонин ${ }^{2}$, Д.Г. Саввакин ${ }^{1}$, В.А. Березос ${ }^{2}$,

В.И. Бондарчук ${ }^{1}$, А.А. Стасюк ${ }^{1}$, П.Е. Марковский ${ }^{1}$

${ }^{1}$ Институт металлофизики им. Г. В. Курдюмова НАН Украины, бульв. Академика Вернадского, 36, 03142 Киев, Украина

${ }^{2}$ Институт электросварки им. Е. О. Патона НАН Украины, ул. Казимира Малевича, 11, 03150 Киев, Украина

\section{ВЛИЯНИЕ МИКРОСТРУКТУРЫ, СПОСОБА И СКОРОСТИ ДЕФОРМАЦИИ НА МЕХАНИЧЕСКОЕ ПОВЕДЕНИЕ \\ СПЛАВОВ Ti-6Al-4V И Ti-1,5Al-6,8Mo-4,5Fe, ПРИГОТОВЛЕННЫХ ЭЛЕКТРОННО-ЛУЧЕВОЙ ПЛАВКОЙ}

На примере двух промышленных экономно легированных титановых сплавов, - малолегированного $\alpha+\beta$-сплава $\mathrm{Ti}-6 \mathrm{Al}-4 \mathrm{~V}$ (масс. \%) и метастабильного $\beta$-сплава Ti-1,5Al-6,8Mo-4,5Fe, - приготовленных однократной электроннолучевой плавкой с промежуточной ёмкостью, изучено влияние формируемой при 
последующих (термомеханической и термической) обработках микроструктуры на механическое поведение (выраженное через энергию деформации $U_{\mathrm{D}}$ ) при испытаниях с разными скоростями деформации и баллистическую стойкость. Установлено, что наименьшая зависимость $U_{\mathrm{D}}$ от скорости деформации соответствует сплаву Ti-6Al-4V с близкой к глобулярной морфологией микроструктуры, в то время как этот же сплав с пластинчатой микроструктурой (после отжига в однофазной $\beta$-области), как и сплав $\mathrm{Ti}-1,5 \mathrm{Al}-6,8 \mathrm{Mo}-4,5 \mathrm{Fe}$ в различных структурных состояниях, характеризуется интенсивным снижением величины $U_{\mathrm{D}}$ с ростом скорости деформации. Кроме того, только отожжённый при температуре двухфазной $\alpha+\beta$-области материал после испытаний на трёхточечный изгиб характеризовался тем, что для каждой скорости деформации величина $U_{\text {D }}$ была равна сумме аналогичных характеристик, полученных испытаниями на растяжение и сжатие. При последующих баллистических испытаниях пластин этих сплавов различной толщины было установлено, что наилучшая баллистическая стойкость соответствует материалам, характеризуемым большими значениями $U_{\mathrm{D}}$ и меньшей её чувствительностью к скорости деформации. Подробно обсуждается повреждение сплавов при испытаниях разных типов с точки зрения вероятных механизмов деформации и разрушения.

Ключевые слова: титановые сплавы, микроструктура, механические свойства, механическое поведение, скорости деформации, энергия деформации, баллистические испытания. 